\title{
Role of histone deacetylases (HDACs) in epilepsy and epileptogenesis
}

${ }^{1}$ Rita Citraro, ${ }^{1}$ Antonio Leo, ${ }^{2}$ Matteo Santoro, ${ }^{3}$ Giuseppe D’Agostino, ${ }^{4}$ Andrew Constanti, $1{ }^{*}$ Emilio Russo

${ }^{1}$ Department of Science of Health, School of Medicine and Surgery, University of Catanzaro, Catanzaro, Italy;

${ }^{2}$ School of Medical Sciences, University of Aberdeen, Institute of Medical Sciences, Foresterhill, Aberdeen, Scotland, U.K.;

${ }^{3}$ Rowett Institute of Nutrition and Health, University of Aberdeen, Aberdeen, United Kingdom;

${ }^{4}$ Department of Pharmacology, UCL School of Pharmacy, 29/39 Brunswick Square, London, UK.

\section{*Corresponding author:}

Prof. Emilio Russo

Department Science of Health, School of Medicine and Surgery, University of Catanzaro;

Viale Europa - Germaneto 88100 Catanzaro, ITALY.

Phone +39 0961 3694191/Fax: +39 0961 3694192; e-mail: erusso@unicz.it

\section{Running title}

Histone deacetylases and epilepsy 


\begin{abstract}
Emerging evidence suggests that epigenetic mechanisms are involved in different brain functions such as the development of the nervous system and normal neuronal function. At the same time, it has been proposed that several neurological diseases are in part, caused by aberrant epigenetic modifications. Nevertheless, the mechanisms underlying pathological alterations in the brain genome are not completely understood. Post-transcriptional histone acetylation is a major mechanism of chromatin remodeling, contributing to epigenetic regulation of gene transcription. Histone deacetylases (HDACs) are a family of proteins involved in both physiological and pathological conditions by regulating the status of chromatin histone acetylation. It is now becoming clear that epigenetic regulatory mechanisms may also play a major role in epilepsy; modulation of chromatin structure through histone modifications has emerged as an important regulator of gene transcription in the brain and altered histone acetylation seems to contribute to changes in gene expression associated with epilepsy and the epileptogenic process. Histone modification is crucial for regulating neurobiological processes such as neural network function, synaptic plasticity, and synaptogenesis which also contribute to the pathophysiology of epilepsy. The role of epigenetics in epilepsy development is a new and emerging research area; the present article reviews the recent findings on the role played by HDACs and the possible function of different histone modifications in epilepsy and epileptogenesis. Inhibitors of HDACs (HDACIs) have been tested in different experimental models of epilepsy with some success. We also review the results from these studies, which indicate HDACIs as potential new therapeutic agents for the treatment of human epilepsy.
\end{abstract}

Keywords: Epigenetics; Chromatin; Histone deacetylase (HDAC); Histone deacetylase inhibitors (HDACIs); Epilepsy, Epileptogenesis; Brain Disorders. 


\section{Introduction}

Epilepsy is a chronic neurological disorder characterized by spontaneous and recurrent epileptic seizures with associated comorbidities. Currently used antiepileptic drugs (AEDs), suppress neuronal hyperexcitability and thereby abolish epileptic seizures but $20-30 \%$ of affected people are refractory to treatment and are considered to have drugresistant epilepsy (DRE)[1]. Furthermore AEDs do not prevent the development and progression of epilepsy (epileptogenesis) [2]. Epileptogenesis is the process by which the brain undergoes molecular and cellular alterations in response to a neuronal insult leading to recurrent spontaneous seizures [3-5]. Several mechanisms are involved in the epileptogenic cascade including neuro-inflammatory responses, neuronal cell loss, mossy fiber sprouting, aberrant connectivity and gliosis [6-8]. Seizures can be triggered by several risk factors including traumatic brain injury, central nervous system (CNS) infections, stroke, hypoxic-ischemic and metabolic disorders, tumors, fever, electrolyte imbalance, drug withdrawal and genetic mutations [2]. In the past two decades, different genetic mutations identified in ion channels or proteins have been directly linked to epileptic syndromes [9, 10]. Recently, it has been suggested that epigenetic mechanisms can also be involved in the pathophysiology of several epileptic disorders. In fact, different forms of epilepsy are caused by abnormalities in factors responsible for chromatin regulation [11-13]. Alterations of epigenetic mechanisms in human tissues and animals with epilepsy are genome-wide and selective for the factors involved in epileptogenesis such as neurotransmitter receptors (e.g, GluR2, GLRA2, and GLRA3), growth factors (e.g, BDNF), and transcriptional regulators (e.g., CREB, c-fos, and c-jun) [14].

Epileptogenesis is associated with different abnormalities of neuronal networks, due to protein posttranslational modifications, activation of immediate early genes (IEGs), and other alterations in the gene expression and function of genes (e.g., GABA $\mathrm{A}_{\mathrm{A}}$ receptor subunits, CREB, BDNF, and EGR3) that eventually lead to deregulated neural circuits with a predisposition for synchronous electrical activity $[3,11]$. Epigenetic mechanisms regulate the neuronal gene expression during brain development and function, synaptic plasticity, memory formation and other processes. Their alterations affect not only normal brain function, but also several brain diseases such as epilepsy [15, 16].

Aberrant patterns of epigenetic modification could erroneously affect gene expression and contribute to pathogenesis or maintenance of the epileptic disease. Epigenetic changes involved in epilepsy and epileptogenesis are represented by covalent modification of DNA, posttranslational histone modifications and chromatin remodeling, and noncoding RNAs [11, 17-19]. Affected genes by these alterations are likely to be involved in neural development, normal neuronal homeostasis and stress responses, neural network function, cell survival, and inflammatory processes [13, 20]. The fact that epigenetic changes might play a significant role in epilepsy (at least in TLE) is important because these changes are potentially reversible. Knowledge of the epigenetic mechanisms implicated in the development of epilepsy could lead to new epigenetic therapies to prevent epilepsy (antiepileptogenic) or its progression (disease modifying). Although DNA methylation changes [13], have been implicated in epileptogenesis, recent evidence points to a critical role of posttranslational histone modifications in the development and progression of epilepsy.

Histone modifications are important for the regulation of neurological processes, such as function of neural networks, synaptic plasticity and synaptogenesis, that seem to be responsible for the epilepsy pathophysiology [11, 21, 22]. Histone deacetylases (HDACs) have shown broad potential in treatments against cancer, and emerging data also support their targeting in CNS dysfunction [23, 24].

HDACs regulate the acetylation of histones in nucleosomes, which mediates changes in chromatin conformation, leading to regulation of gene expression. From available data it appears that histone modifying enzymes are frequently 
identified in epilepsy. Thus, treatment with various HDAC inhibitors (HDACIs) has emerged as a potential therapeutic tool in the treatment of epilepsy [25].

In this review, we will focus on the presumed role of HDACs in experimental and human epilepsy, and particularly in the process of epileptogenesis. We will discuss how epigenetic mechanisms especially histone code modifications can regulate developmental alterations that may contribute to epileptogenesis. Finally, we will also describe the potential of using specific HDACIs as a new pharmacological strategy for epilepsy treatment.

\section{Histones}

In eukaryotic cells, the regulation of gene expression occurs on a complex nuclear structure called chromatin, composed of DNA, special proteins called histones, and non-histone proteins. Histones are a family of conserved basic proteins, which are core components of the nucleosome (fundamental unit of chromatin). The nucleosome contains 147 base pairs of DNA wrapped around the histone octamer composed of two copies each of the histones (H) H2A, H2B, H3, and H4. In addition to providing structural support, histones control accessibility for transcription factors, thereby regulating gene expression [26]. Histone proteins are subjected to different posttranslational modifications on their Nterminal domains, that protrude out of the nucleosome primarily in the $\mathrm{N}$ terminals of $\mathrm{H} 3$ and $\mathrm{H} 4$. These modifications include acetylation, phosphorylation, methylation, ubiquitylation, sumoylation, ribosylation, and citrullination and play an important role in the control of chromatin structure and in the regulation of gene transcription [27]. These modifications most likely act in a combinatorial or sequential fashion, defining the so-called "histone code" which regulates gene expression [28].

One of the most studied posttranslational modifications of histones is the acetylation at lysine residues, which is associated with transcriptional activation [29]. Histone acetylation influences chromatin conformation and affects the accessibility of transcription factors and effector proteins to the DNA, thereby modifying gene expression [30]. The acetylation of histones is regulated by the opposing actions of two different classes of enzymes: histone acetyltransferases (HATs), which transfer acetyl groups to lysine residues on the N-terminal tails of core histones causing a relaxation of chromatin (euchromatin), and histone deacetylases (HDACs), which remove the acetyl groups from lysine residues in the histone tail, thus causing a condensation of chromatin (heterochromatin) [31, 32].

HATs hyperacetylate and lead to a transcriptionally-active chromatin structure and therefore facilitate gene transcription, whereas HDACs deacetylate and suppress transcription and consequently repress gene transcription [33, 34]. A well-balanced regulation of HATs and HDACs is thus essential to gene transcription. The balance between the actions of HATs and HDACs, functions as a key regulatory mechanism for gene expression, controlling different physiological processes and disease states. Acetylation of proteins modulates numerous cellular events that are involved in many biological processes such as cell proliferation, cell survival or apoptosis [35, 36].

Dysregulation of HATs and HDACs can lead to an imbalance between the acetylation and deacetylation of their substrates resulting in altered gene expression that can play a significant role in different human disorders [25, 37, 38]. This alteration was first observed in cancer, many forms of which are linked with increased expression and activity of HDACs $[39,40]$. It is important to underline that dysregulation in the delicate relationship between HAT and HDAC function may lead to cellular dysfunction, including uncontrolled cell growth of abnormal cells and/or apoptosis. For example, excessive deacetylated histones are generally present in pathological conditions, particularly those associated with DNA hypermethylation, chromatin condensation, and gene silencing [41].The best-characterized cellular protein 
that is a positive regulator of histone acetylation is the cyclic AMP (cAMP)-responsive element binding protein (CREB)-binding protein (CBP) [42].

\section{Histone deacetylases (HDACs)}

HDACs are a family of enzymes that play an important role in regulating transcription as well as the function of different cellular proteins. HDACs mediate the deacetylation of histone through the removal of an acetyl group from lysine residues within histone tails, leading to a compacted chromatin structure that results in transcriptional repression [43]. HDACs are involved in both physiological and pathological conditions by regulating the status of histone acetylation. Until now, 18 mammalian HDAC isoforms have been identified and divided into 4 classes based on their function and structural homologies to yeast deacetylase proteins: classes I, II (a and b), III and IV [44-46] . Classes I, II and IV HDACs (“classical," metal-dependent HDAC enzymes) are all zinc dependent enzymes containing zincdependent catalytic domains (Table 1). In contrast, Class III HDACs (nonmetal-dependent enzymes) are zinc independent enzymes and include a family of nicotinamide adenine dinucleotide (NAD)-dependent deacetylases that possess sequence homology with the NAD-dependent HDAC yeast SIR2 protein [47, 48]. These HDAC proteins, in general called 'sirtuins', are structurally and enzymatically different from other HDACs [49, 50].

Class I HDACs include HDACs 1, 2, 3, and 8, and share high sequence homology in their catalytic sites with yeast RPD3 deacetylase. Class I HDACs are expressed ubiquitously, generally localized in the nucleus (with the exception of HDAC3, which can shuttle out to the cytoplasm) and possess high enzymatic activity. Class I HDACs are important in regulating proliferation [51].

Class II HDACs are closely related to yeast HDAC1 and include HDACs 4, 5, 6, 7, 9 and 10. This class is further subdivided into two subclasses: IIa, (HDACs 4, 5, 7 and 9), which contain only one catalytic site and are known to shuttle between cytoplasm and nucleus, and IIb (HDACs 6 and 10), which contain two catalytic sites and are mainly found in the cytoplasm [43, 52].

Class I and II HDACs are widely expressed throughout the brain [53]. Inhibition of these classes of HDACs, enhances levels of histone acetylation producing beneficial effects on host metabolism and brain health.

Class IV HDACs consists of HDAC 11 alone, that is structurally different from class I and class II HDACs but seems to have some properties of both classes. HDAC 11 is expressed in the brain, heart, muscle, kidney and testis, but little is known about its function [36].

The Class III HDACs (Sirtuin family), includes Sirtuin 1, 2, 3, 4, 5, 6, and 7 (SIRTs 1-7). This class, found in the nucleus, cytoplasm and also in mitochondria, is dependent on the co-factor nicotinamide adenine dinucleotide $\left(\mathrm{NAD}^{+}\right)$ $[47,48]$ (Table 1).

The role of HDACs in epigenetic regulation is to invert the effects of HATs, by catalysing the deacetylation of Nterminal tails of histone proteins. This leads to a condensation of chromatin structure which inhibits transcription factor access to DNA, thus producing the transcriptional repression. HDACs are therefore active deacetylating enzymes; however, their activity is not limited to histone proteins. Other than histone proteins, HDACs also deacetylate a great number of non-histone protein substrates, both in the nucleus and in the cytoplasm, such as transcription factors, signalling mediators, cytoskeleton proteins, nuclear hormone receptors, chaperones and other cellular proteins some of which are involved in the tumour progression, cell cycle control, apoptosis, angiogenesis and cell invasion [54]. The structure and activity of these non-histone proteins may be altered by acetylation/deacetylation with subsequent effects on several cell functions including gene expression cell cycle progression, and cell death pathways [55-57]. HDACs are expressed in several tissues, including the brain and spinal cord. Although some HDAC family members have limited 
tissue specificity and central nervous system (CNS) distribution, distinct neurons often express several HDACs [58]. All of the zinc-dependent HDACs are expressed in the brain (Table 1). Isoforms of HDACs class I, II, and IV are expressed principally in neurons, but several classes are present in glia. Although the expression of all HDACs is relatively low in astrocytes, HDACs 2, 3, 4, 5, and 11 are expressed in oligodendrocytes [58]. Of the aforementioned classes of HDACs, classes I and IIa are the most highly expressed in brain regions that are associated with learning and memory [59, 60]. By controlling the status of histone acetylation, HDACs are involved in diverse physiological and pathological processes [61].

Alterations in histone acetylation and related HDACs have been correlated with many diseases, including several forms of cancer, heart failure, inflammatory diseases, and cognitive and psychiatric disorders [24, 62, 63]. Accumulating data suggest that HDACs play important roles in synaptic plasticity, learning, memory, and adult neurogenesis [64-67]. HDACs represent a large and different class of deacetylating enzyme and given their distinct expression patterns in the brain and in the cell, these enzymes are an ideal target for therapeutic inhibition [53]. Therefore, different non-selective and selective HDACIs have been developed [68].

Table 1. Histone deacetylases (HDACs) - classes and isoforms.

\begin{tabular}{|c|c|c|c|c|}
\hline Class & HDACs & Cofactor & Sub-cellular location & Localization in brain \\
\hline Class I & $\begin{array}{l}\text { HDAC1 } \\
\text { HDAC2 } \\
\text { HDAC3 } \\
\text { HDAC8 }\end{array}$ & $\mathrm{Zn}^{2+}$ & $\begin{array}{l}\text { Nucleus } \\
\text { Nucleus } \\
\text { Shuttles between nucleus and } \\
\text { cytoplasm } \\
\text { Nucleus }\end{array}$ & $\begin{array}{l}\text { Cortex, caudate/putamen, } \\
\text { hippocampus, amygdala } \\
\text { SNpc, SNpr, locus coeruleus, corpus } \\
\text { callosum. }\end{array}$ \\
\hline Class IIa & $\begin{array}{l}\text { HDAC4 } \\
\text { HDAC5 } \\
\text { HDAC7 } \\
\text { HDAC9 }\end{array}$ & $\mathrm{Zn}^{2+}$ & $\begin{array}{l}\text { Shuttles between nucleus and } \\
\text { cytoplasm } \\
" \\
" \\
\text { Nucleus-cytoplasm }\end{array}$ & $\begin{array}{l}\text { Cortex, caudate/putamen, } \\
\text { hippocampus, amygdala SNpc, } \\
\text { SNpr, locus coeruleus, globus } \\
\text { Pallidus } \\
\text { Also hippocampus, amygdala } \\
\text { (HDAC 7,9) }\end{array}$ \\
\hline Class IIb & $\begin{array}{l}\text { HDAC6 } \\
\text { HDAC10 } \\
\end{array}$ & $\mathrm{Zn}^{2+}$ & $\begin{array}{l}\text { Cytoplasm } \\
\text { Cytoplasm } \\
\end{array}$ & $\begin{array}{l}\text { Cortex, caudate/putamen } \\
\text { Hippocampus, amygdala, SNpc, } \\
\text { locus coeruleus, cerebellum }\end{array}$ \\
\hline Class III & $\begin{array}{l}\text { SIRT1 } \\
\text { SIRT2 } \\
\text { SIRT3 } \\
\text { SIRT4 } \\
\text { SIRT5 } \\
\text { SIRT6 } \\
\text { SIRT7 } \\
\end{array}$ & $\mathrm{NAD}^{+}$ & $\begin{array}{l}\text { Nucleus } \\
\text { Cytosol } \\
\text { Mitochondria } \\
\text { Mitochondria } \\
\text { Mitochondria } \\
\text { Nucleus } \\
\text { Nucleolus } \\
\end{array}$ & \\
\hline Class IV & HDAC11 & $\mathrm{Zn}^{2+}$ & Nucleus & $\begin{array}{l}\text { Cortex, hippocampus, brain stem, } \\
\text { cerebellum, diencephalon }\end{array}$ \\
\hline
\end{tabular}




\section{Histone deacetylase inhibitors (HDACIs)}

HDACIs are a heterogeneous group of compounds that inhibit HDACs and reestablish or increase the level of histone acetylation of lysine residues in nuclear and cytoplasmic proteins, which may modify their activity and function. HDACIs also promote the acetylation of non-histone proteins which can determine the interactions, localization and stability of these proteins [56, 69]. Treatment with pharmacological HDACIs reverses epigenetic silencing and exerts antineoplastic effects in tissue cultures and animal models of tumorigenesis. Since the deacetylation of histones by HDACs has a repressive activity on gene transcription, treatment with HDACIs stimulates transcriptional activity in cells [69, 70]. Therefore HDAC inhibition has appeared as a possible therapeutic approach to contrary abnormal epigenetic changes associated with cancer and, HDACIs have been shown to cause growth arrest, differentiation and/or apoptosis of many tumours cells by altering the transcription of a small number of genes [71-73]. Consequently, different HDACIs have been studied in clinical trials and commonly used therapeutically as anti-cancer drugs [74-76].

HDACIs, which were initially characterized as anti-cancer drugs, have also recently been proposed to act as neuroprotective agents that enhance the synaptic plasticity, neuronal survival, learning, and memory in different neurodegenerative disorders such as Parkinson' disease (PD), Alzheimer's disease (AD) and Huntington's disease (HD) [77-79]. More recently, there has been interest in the use of HDACIs to activate the expression of mRNAs that are down-regulated in other brain disorders. For these reasons, HDACs represent attractive molecular targets for the treatment of several neurological conditions, and pharmacological therapies using HDACIs have shown beneficial effects in epilepsy, amyotrophic lateral sclerosis (ALS), spinal muscular atrophy (SMA), stroke, Rett syndrome and Fragile X syndrome (affecting girls) [25, 80], as well as a variety of psychiatric diseases (schizophrenia, depression, drug addiction, and anxiety) [62, 81-83].

HDACIs are a family of naturally derived and synthetically produced compounds that can be divided in four main groups based on their chemical structure: hydroxamates, cyclic peptides, the short fatty-chain acids and the benzamides $[35,84]$ (Table 2). HDACIs differ in their specificity for the separate classes of HDACs, although most act on class I and II.

Hydroxamates comprise the largest class of HDACI that act as pan-HDACIs and show low selectivity [23, 84]. Hydroxamate inhibitors possess moderately short half-lives, but exert long-lasting effects. They include trichostatin A (TSA), SAHA (Vorinostat), Panobinostat (LBH589), Belinostat (PXD101), Givinostat (ITF2375), Abexinostat and Dacinostat [84]. These compounds inhibit only class I and II HDACs. A number of these compounds are now in clinical trials investigating for cancer treatment $[75,85]$. Vorinostat is the first HDACI to be Food and Drug Administration (FDA)-approved for clinical treatment of refractory cutaneous T-cell lymphoma (CTCL) [86].

Vorinostat and TSA are two most clinically advanced and most prominent hydroxamate HDACIs, both cross the blood brain barrier (BBB) and could be used for different neurological diseases [77, 87]. TSA is now known to be a broad spectrum pan-HDACI. TSA has been shown to exert anti-inflammatory and neuroprotective effects both in vitro and in vivo models of ischemic stroke. There is also evidence of its neuroprotective effects in numerous models of Parkinsonian cell death [88, 89].

Cyclic peptides: this class of HDACI include compounds such as Apicidin, Trapoxin B and Depsipeptide (FK228)/romidepsin. These compounds specifically inhibit different HDAC isoforms, given that their chemical vary significantly. Apicidin displays selectivity for HDAC2 and HDAC3 (and HDAC8) while FK-228 shows potent efficacy 
for inhibition of HDAC1 and HDAC2 (and HDAC4). FK-228 also was approved by the FDA for the treatment of cutaneous T-cell lymphoma (CTCL) [90, 91].

Short chain fatty acids (SCFAs), comprise compounds relatively small, with simple structure such as Valproic Acid, butyrate and phenyl butyrate. SCFAs all show the same inhibition profile on the HDAC I and IIa classes with most efficacy in inhibiting the HDAC activity than hydroxamates [81]. Due to their capacity to easily cross the BBB, SCFAs are considered a promising class of HDACI for the treatment of neurological diseases [35].

Valproic Acid (VPA) is a short-chain fatty acid used as an anti-epileptic drug, as a mood stabilizer and adjuvant treatment for schizophrenia [92]; it is now the most commonly prescribed anti-epileptic for both generalized and partial seizures in adults and children [93, 94]. VPA is now known as a pan-inhibitor of HDAC classes I and IIa due to its capacity to relieve HDAC-dependent transcriptional repression through the removal of the acetyl group from histones in nucleosomes and cause histone hyperacetylation both in vitro and in vivo [95, 96]. By inhibition of HDACs in various tissues, including the brain, VPA alters the expression of several neuronal, immune and other tissue-specific genes that are thought to explain VPA's therapeutic effects in non-epileptic conditions such as bipolar disorders, schizophrenia, cancer and neurodegenerative diseases [97, 98]. VPA has shown neuroprotective effects in models of traumatic brain injury [99], spinal cord injury [100, 101], stroke [89, 102] PD [103] and AD [104, 105]; the mechanism of neuroprotection implicated thus far includes the elevation of histone 3 (H3) acetylation. Earlier studies in vitro also clearly demonstrated that VPA could promote neuronal survival in cultures subjected to glutamate-induced neurotoxicity [106, 107] or to oxygen-glucose deprivation injury [108]. Recently, this drug has demonstrated antitumor activity as an HDACI [109, 110] with action on cell growth, differentiation and apoptosis [111-114]. It is important to note however, that VPA acts as a nonselective HDACI and possess other mechanisms of action such as targeting the GABAergic system, and can have adverse side effects in clinical patients, making it less than ideal as a therapeutic tool. Indeed teratogenicity (e.g. Fetal Valproate Syndrome) and hepatotoxicity, two rare but lethal side effects, limit the clinical application of valproate [92, 115].

Among SCFAs, butyrate (or sodium butyrate) was one of the first endogenous substances found to have HDACI activity. Butyrate shares inhibition profiles of HDACs with valproate inhibiting classes I and IIa. However, like other SCFAs this is achieved at a relatively low potency [116]. Butyrate has been shown to facilitate neuronal plasticity, longterm memory formation or long-term potentiation (LTP) [117]; also, it has neuroprotective effects and restores cognitive function in experimental models of neurodegeneration (HD and PD, stroke, ALS and ataxias) [118-120] or cognitive impairment [121]. Also it has been shown to induce neurogenesis in the rat brain after cerebral ischemia [122]. Butyrate also reduced depressive-like behavior in animal models showing effectiveness in psychiatric disorders [123, 124]. Both VPA and sodium butyrate also show anti-inflammatory properties [125].

Benzamides, include MS-275 (Entinostat), and Mocetinostat, and represent a highly selective class of HDACI, which show a relatively long half-life as compared with other potent HDACIs (Table 2). Both selectively inhibit HDAC1 (and HDAC3 to a lesser extent) therefore represent a new population of HDACI being designed selectively against individual HDAC isoforms. Two drugs within this class are currently in clinical trial for the treatment of cancers (Grayson et al., 2010). MS-275 has recently received particular attention because of its ability to inhibit HDACs in the brain [126, 127]. These HDACIs may be useful in selectively activating promoters that may be not sufficiently expressed in schizophrenia and other psychiatric disorders [81].

Sirtuin inhibitors (SIRTIs), include the pan-inhibitor nicotinamide and the specific SIRT1 and 2 inhibitors sirtinol, cambinol, and EX-527. 
In summary, treatment with HDACIs has emerged as a promising strategy for intervention in neurodegenerative and neuropsychiatric disorders [77]. Many of these inhibitors are in the final phases of clinical trials and have demonstrated effectiveness in synergistic therapy. For the treatment of brain disorders, an additional challenge is the permeability of the inhibitors across the BBB [25]. Different HDACIs including VPA, vorinostat (SAHA), MS-275, butyrate, and phenyl butyrate have been shown to cross the BBB. In addition, MS-275 seems to be 30 to 100 times more potent than VPA in increasing histone acetylation in vivo [127]. Therefore, MS-275 might be considered a second-generation HDACI with improved specificity, which holds promise not only for cancer treatment [128] but also for various neurological diseases [25].

Table 2. Histone deacetylase inhibitor (HDACI) classification.

\begin{tabular}{|c|c|c|c|c|}
\hline Class & Compound & $\begin{array}{l}\text { HDAC Target } \\
\text { (Potency) }\end{array}$ & $\begin{array}{l}\text { Status in Clinical } \\
\text { Trials for Neurology }\end{array}$ & Diseases Targeted \\
\hline \multirow[t]{10}{*}{ Hydroxamates } & $\begin{array}{l}\text { Trichostatin A } \\
\text { (TSA) }\end{array}$ & $\begin{array}{l}\text { Class I (HDAC } \\
1,2,3,8), \text { II, }(\mathrm{HDAC} \\
4,5,6,7,9,10)(\mu \mathrm{M})\end{array}$ & & Neurodegeneration. \\
\hline & $\begin{array}{l}\text { SAHA } \\
\text { (Vorinostat) }\end{array}$ & $\begin{array}{l}\text { Class I (HDAC } \\
1,2,3,8), \text { II, }(\mathrm{HDAC} \\
4,5,6,7,9,10)(\mu \mathrm{M})\end{array}$ & $\begin{array}{l}\text { FDA-approved (2006) } \\
\text { for CTCL, phase II, } \\
\text { III alone or in } \\
\text { combination }\end{array}$ & $\begin{array}{l}\text { Preclinical: Memory loss, } \\
\text { SMA, Focal Ischemia, } \\
\text { Cognitive disorders, } \\
\text { Glioblastoma. }\end{array}$ \\
\hline & $\mathrm{CBHA}$ & $\begin{array}{l}\text { Sirtuins (HDAC1,3) } \\
\text { N/A }(\mu \mathrm{M})\end{array}$ & & $\begin{array}{l}\text { Preclinical: Axonal } \\
\text { degeneration }\end{array}$ \\
\hline & LAQ-824 & Class I and II (nM) & & \\
\hline & $\begin{array}{l}\text { Belinostat } \\
\text { (PXD101) }\end{array}$ & Class I, II, IV $(\mu \mathrm{M})$ & $\begin{array}{l}\text { Phase I, II alone or in } \\
\text { combination }\end{array}$ & \\
\hline & $\begin{array}{l}\text { Panobinostat } \\
\text { (LBH589) }\end{array}$ & Class I, II, IV (nM) & $\begin{array}{l}\text { Phase II, III alone or } \\
\text { in combination }\end{array}$ & $\begin{array}{l}\text { Preclinical: Triggers the } \\
\text { expression of the protein } \\
\text { Survival Motor Neuron gene } \\
2 \text { (SMN2) in spinal muscular } \\
\text { atrophy fibroblasts } \\
\text { which are inert to VPA } \\
\text { treatment }\end{array}$ \\
\hline & $\begin{array}{l}\text { Givinostat } \\
\text { (ITF2375) }\end{array}$ & Class I and II (nM) & Phase I, II & \\
\hline & $\begin{array}{l}\text { Abexinostat } \\
(\text { PCI-24781) }\end{array}$ & Class I, II, IV (nM) & $\begin{array}{l}\text { Phase I, II alone or in } \\
\text { combination }\end{array}$ & \\
\hline & $\begin{array}{l}\text { Resminostat } \\
\text { (4SC-201) }\end{array}$ & Class I, II, IV $(\mu \mathrm{M})$ & $\begin{array}{l}\text { Phase I, II alone or in } \\
\text { combination }\end{array}$ & \\
\hline & $\begin{array}{l}\text { Quisinostat } \\
\text { (JNJ-26481585) }\end{array}$ & Class I, II, IV $(\mu \mathrm{M})$ & Phase I & \\
\hline \multirow[t]{2}{*}{ Cyclic peptide } & $\begin{array}{l}\text { Depsipeptide } \\
(\mathrm{FK}-228) / \\
\text { romidepsin }\end{array}$ & $\begin{array}{l}\text { Class I (HDAC1,2,4,6) } \\
(\mathrm{nM})\end{array}$ & $\begin{array}{l}\text { FDA-approved (2009) } \\
\text { for CTCL and PCTL, } \\
\text { phase I, II alone or in } \\
\text { combination }\end{array}$ & $\begin{array}{l}\text { Preclinical: } \\
\text { Neurodegeneration, } \\
\text { Depression, Neuroblastoma }\end{array}$ \\
\hline & Apicidin & $\begin{array}{l}\text { Classes I and II (nM to } \\
\mu \mathrm{M})(\mathrm{HDAC} 2,3)\end{array}$ & & $\begin{array}{l}\text { Preclinical: } \\
\text { Neurodegeneration, } \\
\text { Depression }\end{array}$ \\
\hline $\begin{array}{l}\text { Short chain } \\
\text { fatty acids } \\
\text { (SCFAs) }\end{array}$ & Valproic Acid & $\begin{array}{l}\text { Class I (HDAC 1,2,3,8) } \\
\text { and IIa (HDAC 4,5,7,9) } \\
(\mathrm{mM})\end{array}$ & $\begin{array}{l}\text { Phase I, II, III alone or } \\
\text { in combination } \\
\text { Double blind } \\
\text { randomized placebo } \\
\text { controlled trial in } \\
\text { SMA (NCT01671384, }\end{array}$ & $\begin{array}{l}\text { Brain Ischemia, Stroke, } \\
\text { reversal of contextual } \\
\text { memory deficits, SMA, AD. }\end{array}$ \\
\hline
\end{tabular}




\begin{tabular}{|c|c|c|c|c|}
\hline & & & $\begin{array}{l}\text { NCT00661453); } \\
\text { Double-blind } \\
\text { randomised placebo } \\
\text { controlled trial in AD } \\
\text { (NCT00071721). }\end{array}$ & \\
\hline & Phenyl butyrate & Class I and IIa (mM) & $\begin{array}{l}\text { Safety and tolerability } \\
\text { study in HD } \\
\text { (NCT00212316) }\end{array}$ & Axonal degeneration, HD \\
\hline & Butyrate & Class I and IIa (mM) & $\begin{array}{l}\text { Phase II alone or in } \\
\text { combination } \\
\text { Phase II - dose } \\
\text { tolerability study in } \\
\text { ALS }\end{array}$ & $\begin{array}{l}\text { Memory loss, Depression, } \\
\text { Fear, improved learning and } \\
\text { memory, reversal of } \\
\text { contextual } \\
\text { memory deficits, restoration } \\
\text { of dendritic spine } \\
\text { density in hippocampal } \\
\text { neurons, alleviation of } \\
\text { cognitive defects }\end{array}$ \\
\hline Benzamides & $\begin{array}{l}\text { Entinostat } \\
\text { (MS-275) }\end{array}$ & $\begin{array}{l}\text { Class I (HDAC } 1,2,3,9) \\
(\mu \mathrm{M})\end{array}$ & $\begin{array}{l}\text { Phase II alone or in } \\
\text { combination }\end{array}$ & $\begin{array}{l}\text { Preclinical: Duchenne } \\
\text { muscular dystrophy, reduced } \\
\text { neuroinflammation and } \\
\text { cerebral amylodosis }\end{array}$ \\
\hline & $\begin{array}{l}\text { Mocetinostat } \\
\text { (MGCD0103) }\end{array}$ & $\begin{array}{l}\text { Class I (HDAC 2, 3, } \\
11)(\mu \mathrm{M})\end{array}$ & $\begin{array}{l}\text { Phase I, II alone or in } \\
\text { combination }\end{array}$ & $\begin{array}{l}\text { Preclinical: } \\
\text { Neurodegeneration }\end{array}$ \\
\hline & CI-994 & HDAC1, HDAC3 $(\mu \mathrm{M})$ & & \\
\hline & Belinostat & HDAC 1-10 $(\mu \mathrm{M})$ & & Preclinical: Glioma treatment \\
\hline & Mocetinostat & HDAC $1,2,3,11(\mu \mathrm{M})$ & & $\begin{array}{l}\text { Preclinical: Post-ischemic } \\
\text { fibrosis }\end{array}$ \\
\hline & Crebinostat & HDAC1,2,3,6 $(\mu \mathrm{M})$ & & $\begin{array}{l}\text { Preclinical: Enhances } \\
\text { memory formation, Enhances } \\
\text { neurotropic factors and } \\
\text { neurite growth }\end{array}$ \\
\hline
\end{tabular}

\section{Histone deacetylases and brain disease}

Alterations in levels or homeostasis of acetylation are considered as a major signaling event in different clinical diseases such as cancer and CNS diseases. Hypoacetylation of histone, which is mediated by histone deacetylase (HDAC), plays a relevant role in the etiology of several brain disorders as such neurodegenerative and neurodevelopmental cognitive disorders and psychiatric diseases $[62,80,129,130]$.

\section{Memory and learning}

Chromatin alterations via histone acetylation are involved in the regulation of learning, memory synaptic plasticity as well as adult neurogenesis $[65,67,117,131]$. Acetylation of the hippocampal histones (H2B, H3, and H4) are transiently increased in normal mice during learning processes, suggesting that histone acetylation is essential for memory consolidation [132-134]. In mouse models, changes in histone acetylation have been associated with cognitive impairment, particularly in learning and memory [135-137]. It was first reported that an overexpression neuron-specific HDAC2 decreases dendritic spine density, synapse number, synaptic plasticity, and memory formation in mice; instead, HDAC2 deletion leads to increase synapse number and improvements of learning and memory supporting the crucial role of histone acetylation and deacetylation in human diseases associated with memory impairment, such as AD [134, 138]. It has also been shown that deletion of both HDAC1 and HDAC2 in mice during embryogenesis causes 
abnormalities in hippocampal, cortical, and cerebellar development, as well as lethality because of triggered apoptosis [139].

Increasing evidence suggests that adult neurons respond to various environmental signals via dynamic changes in DNA methylation and histone modifications. These processes are important to mechanisms of memory formation and cognition via modulation of genes involved in synaptic plasticity, such as brain-derived neurotrophic factor (BDNF) and reelin [131, 140]. Therefore, inhibition of the catalytic activity of HDAC could serve as a therapeutic approach towards enhancing the learning and memory processes for different neurodegenerative diseases [104, 141].

\section{Neurodegenerative diseases}

Changes in chromatin structure due to post-translational modifications of histones can also be associated with different neurodevelopmental disorders (such as Rubinstein-Taybi syndrome and Rett syndrome, Fragile X syndrome) and neurodegenerative diseases (AD, HD and PD) $[25,53,77,142]$. Chronic dysregulation of the acetylation/deacetylation activity can lead to neuronal cell death as manifested in neurodegenerative disorders [143]. Rouaux and colleagues were the first to find decreased levels of histone neuronal acetylation in neurodegeneration [144]. Since then, the linkage between histone hypoacetylation and neurodegeneration has been well established in many cognitive and movement disorders [103, 145-147].

The HDAC proteins may regulate the level of histone acetylation and the expression of some important genes, which are associated with the memory and cognition, involved in AD [146, 148]. An increased expression of HDAC2 and HDAC6 with subsequent hypoacetylation of histones has been found in the brains of AD patients and in AD model mice that may contribute to learning and memory deficits in this disease $[149,150]$.

HDACIs exhibit neuroprotective and neuroregenerative properties in animal model of these disorders [151]. HDACIs (such as VPA, butyrate, or SAHA) restore histone acetylation status ameliorating cognitive deficits and memory impairment in various AD animal models [104, 105]; the neuroprotective efficacy of HDACIs can be due to downregulation of neurotoxic proteins or factors like $\beta$-amyloid $(\mathrm{A} \beta)$ peptide, inhibition of $A \beta$-induced hyperphosphorylation of tau protein and up-regulation of neuroprotective factors [105, 146]. Moreover, it has been suggested that the effect of HDACIs in AD was also mediated by increasing the expression of neuroprotective factors, including progranulin, BDNF and gelsolin [152, 153].

Lacosamide, is an HDAC inhibitor, developed for the treatment of epilepsy [154]. HDAC plays an important role in memory and in AD [146]. Recently it has been found that Lacosamide at a dose of $30 \mathrm{mg} / \mathrm{kg}$ reduced the HDAC levels in the cerebral cortex indicating memory-enhancing potential, which can be well correlated with an improvement in memory in of AD [155].

Altered neuronal histone acetylation is an important early feature also of HD [156, 157]. The therapeutic potential of HDACIs has also been evaluated in various animal models of HD reporting that SAHA, butyrate, phenylbutyrate, TSA, and VPA improve the motor impairment in these models [118, 158-160]. This improvement in motor performance is consistently associated with increased histone acetylation and thus, strongly points towards a loss of neuronal acetylation homeostasis during neurodegeneration [145, 161]. It has been suggested that the pathophysiology of HD is intimately coupled to BDNF and HSP70 deficiency in affected brain regions [162]. Since the expression of both BDNF and HSP70 is regulated by class I and II HDACIs, it is conceivable that restoring BDNF and HSP70 to their normal levels contributes to the beneficial effects of HDACIs in various HD models [77]. Thomas et al. found that an SAHA- 
related HDACI called HDACI $4 \mathrm{~b}$ could ameliorate the disease phenotypes in HD transgenic mice even when the treatment was initiated after the onset of motor deficits [163].

Several HDACIs which are undergoing clinical trials have, or currently include, patients with HD; some of these studies have indicated beneficial effects of VPA in myoclonic hyperkinesias in HD patients, suggesting the possible application of VPA as an alternative treatment for HD [164].

Alterations in histone modifications are also involved in PD and treatment with HDACIs result in beneficial effects in in vivo and in vitro models of PD [165-167]. HDACIs improved the neurodegeneration involved in PD through the protection of dopamine neurons or increase of dopamine level; furthermore, the effect of HDACIs on the dopamine neurons was also mediated by increasing the expression of neurotrophic factors, including GDNF and BDNF in astrocytes to protect DA neurons [147, 168-170]. Therefore, the potential therapeutic effectiveness of HDACIs in PD is via neuroprotection in two ways: 1) down-regulation of neurotoxic proteins or factors like $\alpha$-synuclein, rotenone, and MPTP; 2) up-regulation of neurotrophic factors like GDNF and BDNF. Some clinical trials have also been initiated to investigate the possible therapeutic potential of HDACIs in patients with PD [147].

Epigenetic alterations have also been described in other neurodegenerative pathologies, such as ALS and SMA [171, 172]. ALS is familial and associated with mutation in the Super Oxide Dismutase (SOD1) gene; VPA treatment has been shown to improve the survival of ALS mouse models with an SOD mutation (SOD1/G93A) [173]. Other authors have also found that, in SOD1 mutant mice, VPA treatment, maintained normal levels of histone acetylation, significantly suppressed the death of motor neurons, with beneficial effects on motor dysfunction onset, motor deficits, and survival time $[118,174,175]$. 4-phenylbutyrate administration in transgenic ALS mouse models before or shortly after symptom onset resulted in extended survival and improved pathological phenotypes [176]. In the same ALS transgenic mice, combined treatment with phenyl butyrate and riluzole, the only FDA-approved drug for treating ALS, was more effective than either drug alone in increasing survival and improving pathological phenotypes [177].

The homozygous deletion of the $S M N$ gene that encodes the full-length survival motor neuron protein plays a genetic causative role in the SMA disorder. HDACIs (butyrate, 4-phenylbutyrate, VPA, SAHA, TSA and romidepsin) showed neuroprotective effects in this disorder via an increase of histone acetylation of the $S M N$ promoter with consequent increased $S M N$ gene expression and protein levels [178-181].

Recent studies indicate that butyrate may be useful to ameliorate neurological symptoms and motor function as well as suppressed spinal motor neuronal degeneration and muscular atrophy and increase survival in models of SMA [182184]. SAHA treatment was found to prevent death and improve survival in two transgenic mouse models of SMA [185]. Different studies in SMA patients showed that HDACIs (4-phenyl butyrate, VPA and M344) increased transcription of SMN2 and altered the splicing pattern to produce more full-length protein encoded by SMN2 [179, 186188]. Sodium 4-phenylbutyrate increased the expression of SMN protein in the leukocytes of SMA patients [189]. Patients with type III/IV SMA treated with VPA for 8 months showed an increased muscle strength and function [190]. VPA was also found to decrease the excitation in the axon terminals of motorneurons in lymphoblastoid cells isolated from SMA patients. This inhibitor additionally showed inhibition of the voltage-gated $\mathrm{Ca}^{2+}$ channels essential for motor neuron excitation [191]. In addition to neurodegenerative disorders, HDACIs may have the potential to treat neurodevelopmental disorders such as Rubinstein-Taybi syndrome and Rett's syndrome that are caused by mutations affecting transcriptional and epigenetic mechanisms [25, 137]. 


\section{Stroke}

Histone hypoacetylation was found in the ischemic brain of the middle cerebral artery occlusion (MCAO) stroke model of rats or mice, which could be restored by treatment with HDACIs, preventing neuronal death [89, 192]. HDACIs also altered the expression patterns of genes involved in protecting ischemic insult by increasing the acetylation patterns of core histone H3, ameliorating neuronal death and cognitive deficits in mouse models of focal ischemia [193]. Thus, different studies have shown the ability of HDACIs to exert neuroprotection in the MCAO models of ischemic stroke [194]; administration of SAHA after induction of ischemic stroke by MCAO prevented H3 deacetylation, stimulated the expression of some neuroprotective proteins (Bcl-2 and Hsp70), and reduced infarct volume, indicating a neuroprotective action for SAHA [195]. Similar protection against brain injury and neurological deficits caused by ischemic stroke has been described following administration of VPA. VPA stimulated HSP70 expression and histone H3 acetylation [192]. The HDACI TSA, conferred stroke protection in wild-type mice subjected to mild, but not severe ischemic damage [196]. TSA ameliorated neuronal injury in wild-type mice subjected to MCAO in vivo [197] further emphasizing the role of histone acetylation in ischemia-induced neuronal death. The effectiveness of HDACIs seems to be due to their anti-inflammatory effects via their down-regulation of specific proteins, nuclear factors, proinflammatory factors, enzymes (like IL-6, NF-kB, iNOS, TNF-a, COX-2, MMP-9 and MCP-1) which were induced or activated by ischemia in the ischemic brain but also to their neuroprotective effects via up-regulation of neuroprotective factors or proteins like HSP70, BDNF and gelsolin [193, 198].

\section{Psychiatric disorders}

Evidence derived mostly from a large body of research in animal models suggests that histone modifications also play an important role in numerous psychiatric disorders, including schizophrenia, depression, drug addiction and anxiety disorders [15, 199-201]. Class I and II HDACs are modified in psychiatric diseases making these of interest as drug targets [83, 202, 203]. Alterations in HDAC activity are associated with bipolar disorder (BD) and VPA is used for BD patients who are resistant to lithium therapy [204].

The involvement of HDAC dysfunction in the pathophysiology of mood disorders was also shown for instance, by an increased expression of HDAC2 and HDAC5 mRNA in the peripheral blood cells of patients with major depressive disorders (MDD) and BD during depressive episodes, suggesting that an altered expression of HDACs may be associated with the pathophysiology of depression [205]. In a postmortem study, individuals with BD had higher baseline levels of total acetylated histone 3 levels compared to subjects with schizophrenia [206, 207].

It has also been found that an enhanced acetylated histone H3 occurs, associated with decreased levels of HDAC2 expression in the nucleus accumbes (NAc) of mice subjected to chronic social defeat stress, a validated model of depression [83, 208, 209]. Similar effects has been observed in the NAc of individuals with MDD, demonstrating the relevance of chromatin remodeling in human depression $[82,83,210]$. Due to their potential ability to reverse dysfunctional epigenetic regulation, diverse CNS-penetrant HDACIs have been suggested as potential therapies for the treatment of mood disorders. Interestingly, butyrate shows antidepressant properties and enhances the efficacy of the selective serotonin reuptake inhibitor fluoxetine [81, 123, 200, 211]. Administration of HDACIs (SAHA and MS-275) in the NAc, hippocampus and amygdala, results in increased acetylation of histone $\mathrm{H} 3$ and significant antidepressant like effects in the chronic social defeat stress model in mice, indicating that directly targeting HDAC may be a new approach for the treatment of depression and mood disorders [83, 212]. 
Anxiety is often present in mood disorders. In models of anxiety such as extinction of conditioned fear, a significant increase in histone $\mathrm{H} 4$ acetylation around the BDNF P4 gene promoter was found; VPA treatment potentiated the effect of weak extinction training on histone $\mathrm{H} 4$ acetylation around both the BDNF P1 and P4 gene promoters and on BDNF exon IV mRNA expression [213]. This suggests that HDACIs may become a useful pharmacological adjunct to standard psychotherapy for human anxiety disorders. Other studies found that HDACIs enhanced initial learning in contextual fear conditioning, possibly involving the ERK/MAPK pathway, associated with the pathophysiology of mood disorders [214, 215].

In summary, in disorders of the brain, in which the dysregulation of gene expression has been implicated in different neurological and psychiatric diseases, there is enormous potential to restore patterns of gene expression and neuronal function through the use of epigenetic drugs. Furthermore, HDACIs also hold promise for therapy relevant to several neurological disorders [199]. For these reasons, HDACs represent attractive molecular targets for the treatment of these diseases $[141,216]$.

\section{Histone deacetylases and epilepsy}

For many years, it has been assumed that epilepsy occurs only as a result of cortical damage. Today, it is known that epilepsy can also arise as a consequence of traumatic brain injury, stroke, brain abnormalities, toxic-metabolic factors, inflammation, autoimmunity, or an imbalance in inhibitory and excitatory synaptic transmission [217]. Epilepsy can also arise as a consequence of spontaneous or inherited gene mutations, the latter including many channelopathies, in which epileptic seizures arise due to mutations in neuronal ion-channel genes or in other genes that control development and neuronal function of the brain [218, 219].

In the past few years, many genes have been linked to epilepsy and control voltage-gate channels (e.g. $\mathrm{Na}^{+}, \mathrm{K}^{+}, \mathrm{Ca}^{2+}$, and $\mathrm{Cl}^{-}$) or ligand-gated channels (e.g. nicotinic acetylcholine and GABA receptors). Alterations not only in transcription, but also covalent modifications of DNA, histone code modifications, chromatin remodeling, and noncoding RNA (ncRNA) expression are involved in the pathogenesis of epilepsy and in the process of epileptogenesis $[11,13]$.

Altered gene expression may be related to molecular and cellular mechanisms of normal neuronal homeostasis, excitability, cell survival, and inflammatory processes leading to the development of epilepsy $[8,14,20]$.

Epigenetic modifications affect the expression of genes encoding epigenetic proteins as growth or transcription factors, inflammation associated proteins and neuropeptides involved in epilepsy. In particular, abnormalities of neural network by posttranslational modifications of proteins include increased expression of immediate early genes (IEGs), growth factor (BDNF), diverse transcriptional regulators (e.g. CREB, $c$-fos, and c-jun), $\mathrm{GABA}_{\mathrm{A}}$ receptor subunit composition. and the glutamate receptor 2 (GluR2) AMPA receptor subunit that lead to deregulated neural circuits and a predisposition towards epileptic seizures [3, 220-222]. The epilepsy-induced changes in gene expression of several proteins are probably guided by epigenetic mechanisms, comprising chromatin modifications such as histone modifications [223, 224]. Epigenetic factors such as HDACs can modulate many processes such as neurogenesis and gliogenesis, neural cell migration, and synaptic plasticity; dysregulation of these epigenetic factors can lead to apoptosis, aberrant neuronal migration, impaired glial function, neuronal hyperexcitability, all of which can contribute

to epileptogenesis, and epilepsy. Moreover, the hyperexcitability associated with epilepsy can also impact the expression of genes that regulate the epigenetic state [11,22]. Although only limited studies have investigated histone 
modifications in epilepsy, recent evidence has now described that posttranslational histone modifications represent an epigenetic mechanism that affects the epileptic disease [225]. Abnormal histone modifications and altered gene expression are hallmark features of animal models of status epilepticus (SE) and human temporal lobe epilepsy (TLE) [13]. Emerging data have recently demonstrated that both chemically or electrically induced-seizures influence histone modifications in vivo [226-229] (Table 3). Induction of SE or prolonged seizures by pilocarpine or kainate can trigger numerous changes in gene expression (as gene upregulation) that are thought to contribute to the development of epilepsy [230, 231].

Kainate stimulation induces the expression of several IEGs including two commonly used markers, $c$-fos and $c$-jun genes in neurons in vivo and in vitro. IEGs belong to a class of genes that are rapidly induced, usually in a transient fashion, in response to intracellular signaling cascades. Among IEGs, $c$-fos and $c$-jun gene induction by different stimuli have been associated with histone modifications. Studies in vitro showed that $c$-fos induction is associated with histone H3 phosphorylation [232], while both of $c$-fos and c-jun inductions are associated with both histone H3 phosphorylation and $\mathrm{H} 4$ acetylation [233, 234].

Emerging evidence has demonstrated marked and different changes in the expression of the class I and class IV HDACs as well as class II HDACs in two mouse TLE models after an acute SE, during epileptogenesis and in chronic epilepsy $[235,236]$. A marked decrease in the expression of the class I HDAC (1 and 2) and class IV HDAC (11) in the granule cell and pyramidal cell layers of the hippocampus during acute pilocarpine and kainate-induced SE has also been found [235] (Table 3).

The decrease HDAC expression may cause an augmented acetylation state of histones and thus induce increased expression of numerous genes; indeed, the decreased expression of class I HDAC in both seizure models contributes to hyperacetylation of $\mathrm{H} 4$ histone at $c$-fos, $c$-jun and BDNF promoters and increased $c$-fos, $c$-jun and BDNF expression [226, 228, 229]. It is worth noting that BDNF can exert both pro- and anti-convulsive/-epileptogenic actions [237, 238].

The kainate-induced SE in rats promotes a rapid but temporary phosphorylation of histone $\mathrm{H} 3$ and a histone $\mathrm{H} 4$ hyperacetylation, correlated with induced mRNA expression of $c$-fos and c-jun genes particularly in dentate gyrus neurons of the hippocampus [229]. Both histone modifications are associated with the $c$-fos gene promoter after kainate stimulation, while only histone acetylation with the $c$-jun gene $[229,239,240]$. c-fos and c-jun are a subgroup of inducible transcription factors known as IEGs, activated rapidly and transiently in response to cellular stimuli and stimulate cell growth, differentiation signals, and neuronal survival.

Pretreatment with TSA, a potent HDACI, increased the basal level of histone H4 acetylation and the $c$-fos and $c$-jun genes expression in the hippocampus after kainate administration suggesting that the expression of these IEGs is regulated by gene-specific histone modifications in neurons. Histone acetylation might play a role in the regulation of both gene expressions after kainate stimulation [229, 239, 240]. Interestingly, it has also found that pretreatment with curcumin (an anti-inflammatory constituent of turmeric), which has a HAT inhibitory activity specific for CBP/p300, decreased the level of histone $\mathrm{H} 3$ phosphorylation, the expression of IEGs (c-fos and $c$-jun), and also reduced the severity of kainate-induced SE [229, 239]. Therefore, histone modifications induced by kainate may have a crucial role not only in IEG expression but also in the development of epilepsy. An important increase in H3 phosphorylation was found in some brain structures after pilocarpine-induced SE that significantly seem to depend on neuronal excitation. The excessive neuronal excitation induces chromatin remodeling in neurons, thereby altering gene expression; $\mathrm{H} 3$ phosphorylation is a good indicator of strong neuronal excitation [241]. 
Jagiardar et al., 2015 showed also that in the chronic phase of kainate-induced seizures, only class I HDAC (1, 2, 3, and 8) mRNAs was significantly up-regulated in the hippocampus. Similar changes were detected after a pilocarpineinduced SE except that a decrease in HDACs 3 and 8 were also seen at the chronic phase [235]. The increased expression of all class I HDACs during the epileptogenic phase, can be related to decreased histone acetylation, which could lead to decreased expression of certain proteins and thereby promote epileptogenesis. Thus, addressing HDAC expression may have a therapeutic potential in interfering with SE and with the manifestation of TLE [235].

This finding is consistent with an upregulation of HDAC2 protein in patients with TLE and in the lithium-pilocarpine rat model of induced seizures (TLE) [242]. The increased HDAC2 expression level during the acute and chronic period TLE rat model in the hippocampus and adjacent cortex seems to enhance neuronal excitability and promote excitatory circuit reorganization that lead to epilepsy. Also, abnormal HDAC2 expression in patients with TLE is consistent with a possible role of this protein in the pathophysiology of TLE. It has been supposed that HDAC2 may be implicated in enhancing neuronal excitability via regulating synaptic plasticity and lead to epileptic discharges. In particular, an upregulation of HDAC2 protein in TLE patients suggests that the activity of HDAC2 protein synthesis could be one step in a group of different events that induce changes of synaptic plasticity-related gene expression in the epileptic temporal neocortex area [242]. Changes in the expression patterns of class II HDACs mRNAs have also been found by [236] in the same animal models of kainate- and pilocarpine-induced epilepsy [236]. Nevertheless, in contrast to the class I and IV HDACs, the expression of class II HDACs (5 and 9), was markedly increased during the SE [235](Table 3).

Up-regulated expression of HDAC5 and 9 mRNAs, that coincided with pronounced granule cell dispersion in the hippocampus, were observed after kainate injection; this increase seems to be related to the highest period of seizure activity during the SE. This increased expression may result in reduced acetylation of histones $\mathrm{H} 3$ and $\mathrm{H} 4$ at some promoters and consequently in down-regulation of some genes. In contrast, in the pilocarpine model, that does not show granule cell dispersion, a marked down-regulation of the class II HDAC 5 and 9 mRNAs has been observed; these changes in the pilocarpine model may also be associated with the SE of the animals. This particular pattern of HDAC mRNA expression suggests a role in epileptogenesis and granule cell dispersion [236].

Crosio et al. (2003) have also reported that kainate or pilocarpine-induced seizures promote chromatin remodeling in hippocampal neurons, including transient hyperphosphorylation of histone $\mathrm{H} 3$ at serine 10 and acetylation at lysine 14 [227]. These histone modifications are coupled with rapid activation of extracellular regulated kinase (ERK) and with $c$ fos upregulation which are mechanisms that mediate epileptogenesis [227, 243]. Therefore, H3 phosphorylation at Serine10 and acetylation at Lisine14 are normally used markers for identifying histone modification [227, 229] (Table 3).

Other studies have shown that electroconvulsive seizures induce histone H4 hyperacetylation at $c$-fos and BDNF gene promoters, while decreasing acetylation levels at the CREB promoter, in correlation with mRNA levels of these genes [228]. BDNF upregulation following seizure activity was believed to contribute to epileptogenesis, and BDNF administration in epileptic animals can trigger seizures [244].

CREB is an important transcription factor, involved in the transcriptional control of different genes, many of which are rapidly expressed in response to an increase of cytoplasmic cAMP or $\mathrm{Ca}^{2+}$ levels (as are IEGs). Therefore, CREB may be involved in inducing IEGs in seizure activity. Furthermore, CREB is important for controlling activity-dependent processes in neurons; among other activities, it modulates the expression of the $\mathrm{GABA}_{\mathrm{A}}$ receptor in the hippocampus and plays an important role in the epileptogenic process. Activation of CREB and ERK appears to modulate seizure 
susceptibility in both human and animal epilepsy models [245-249]. Changes in the state of chromatin affect the expression of specific genes involved in seizure generation. The expression of HDAC2, a class I HDAC implicated in brain development, is up-regulated in experimental and human epilepsy [226, 242]; the effects of changes in HDAC activity comprise transcriptional responses for several genes implicated in synaptic function, including ionotropic and metabotropic glutamate receptors [250]. Epigenetic changes are also observed following electroconvulsive seizures (ECS); repeated treatment with ECS induces an up-regulation of HDAC2 expression, correlated with reduced expression of genes involved in the N-methyl-D-aspartate (NMDA) receptor signaling pathway in the rat frontal cortex [251].

Repeated ECS treatments caused down regulation of c-Fos Egr1, Nrn1, Nr2a, Nr2b, and Camk2 $\alpha$, which are major components of NMDA receptor-related signaling, and down regulation of histone deacetylation in their promoter region in the rat frontal cortex and hippocampus. This alteration suggests that histone modifications could play an important role in ECS-induced gene expression changes [228, 251]. Administration of butyrate, recovered the ECS-induced downregulation of genes in the rat frontal cortex [252].

Epileptic seizures produce gene expression changes, including alterations in mRNA levels for glutamate receptor 2 (GluR2) and BDNF, two well-characterized epileptogenesis-related genes. Huang et al. (2002) showed an increased histone $\mathrm{H} 4$ acetylation at the BDNF gene promoter, but a reduction of histone $\mathrm{H} 4$ acetylation at the GluR2 (a subunit of the AMPA receptor) gene promoter after pilocarpine-induced SE in rat hippocampal CA3 neurons [226] as an early event in SE. The expression of the AMPA receptor subunit GluR2 was suppressed, leading to an increase in GluR2lacking AMPA receptors ( $\mathrm{Ca}^{2+}$-permeable), at hippocampal synapses and neuronal hippocampal death [220, 221, 226] while BDNF expression was increased [222, 228, 253] (Table 3).

Decreased expression of GluR2 in animal models of epilepsy results in potent AMPA receptor-mediated pro-convulsive effects [221, 254]; therefore, the alterations in expression of these proteins contributes to the pathophysiology of recurrent seizures [220]. Interestingly, pretreatment with TSA prevented and rapidly reversed deacetylation of histone $\mathrm{H} 4$ associated with the GluR2 promoter (encoding the GluA2, a subunit of the AMPA receptor that restricts $\mathrm{Ca}^{2+}$ permeability and therefore possesses neuroprotective effects) suggesting that gene-specific changes in histone acetylation may be responsible for pathological processes triggered by SE. Thus, changes in chromatin structure potentially involved in the process of epileptogenesis and HDACi demonstrate to reverse the seizure-induced decrease in histone acetylation at specific epileptogenesis-related genes like GluR2 [226].

It has also been shown that a mouse model lacking histone deacetylase 4 (HDAC4) exhibited spontaneous convulsions [255]. HDAC4 has been implicated in neuronal function and survival [256, 257], therefore, loss of HDAC4 could lead to a dysfunction of synaptic transmission and neuronal excitability that underlies epileptic seizures [255].

Recent evidence has shown that kainite (KA)-induced seizures cause an increased histone H3, acetylated at lysine 9 of the TLR4 gene; pretreatment with SAHA suppressed seizures and inflammatory mediator production by inhibiting the TLR4/MyD88 signaling pathway associated with activated microglia. SAHA suppressed H3K9 acetylation levels and then reduced TLR4 gene expression in KA-induced seizures. Thus, SAHA possesses antiepileptic and neuroprotective effects providing new insights into its possible use as a protective compound against seizure-induced brain damage [258]. The important epilepsy-triggered changes may be guided by epigenetic mechanisms [223, 224].

Finally, it is worth mentioning that the expression of sirtuins (SIRTs) is also altered in epilepsy. The sirtuin SIRT1, a protein deacetylase with nuclear and cytoplasmatic functions, is lastingly over-expressed in the kindling inducedlithium/pilocarpine model of epilepsy and in human TLE, indicating an important role of this protein deacetylase in the 
pathogenesis of epilepsy [259]. In addition, SIRT4, a mitochondrial sirtuin, is up-regulated after administration of KA in wild-type mice. In SIRT4 knockout (KO) mice, the loss of SIRT4 leads to a more severe reaction to KA and decreased glutamate uptake that is correlated with a decreased glutamate transporter expression and function in the brain. Consequently, SIRT4 may protect against excitotoxicity by promoting glutamate uptake in the brain, and loss of SIRT4 increases sensitivity to excitotoxic insults. This neuroprotective role of SIRT4 has implications in epilepsy, but also for other brain disorders such as traumatic brain injury, and neurodegeneration [260]. Recently Li and Liu 2016 have found an important association between SIRT5, (mostly expressed in the brain) and epilepsy. SIRT5 knockout (KO) mice show an increased KA-induced seizure susceptibility compared to wild type controls; SIRT5 deficiency greatly exacerbated severity and mortality of seizures, dramatically increased hippocampal neuronal death and degeneration in mice exposed to KA, supporting the neuroprotective role of SIRT5 in this seizure model [261].

In summary, the above studies illustrate the effect of epigenetic mechanisms, in the form of histone modifications, on the regulation of genes implicated in control of epileptiform activity. Therefore, epigenetic mechanisms like altered histone acetylation may have a crucial role in epilepsy and epileptogenesis. These studies suggest a crucial role of expression of HDACs in the epigenetic regulation of seizure-induced expression of neuropeptides and proteins and thereby promote the development of epilepsy as well as the formation of anticonvulsive mechanisms.

A number of drugs that target the epigenetic machinery are consequently, potential therapeutic agents for epilepsy. The most common HDACIs in clinical trials to date are the short-chain fatty acids, (such as butyrate, phenyl butyrate, and VPA), and the hyroxamic acids, (such as TSA and SAHA) (Abel and Zukin, 2008). SAHA and TSA promote neuronal survival in animal models of epilepsy [224, 226, 240]. VPA has been used to control seizures for decades in patients with epilepsy and was also found to be a potent inhibitor of class-I HDAC isoforms in addition to effects on ion channels and neurotransmission [112]. Interestingly, the anticonvulsant effects of VPA increase over time, which could be consistent with an epigenetic effect on gene transcription. Unfortunately, long-term treatment with VPA may be associated with serious toxic effects, since VPA administration in pregnant epilepsy patients is known to cause neonatal malformations [262]. VPA also increases expression of neuropeptide $\mathrm{Y}$ in the reticular nucleus thalami of rats suggesting that the expression of neuropeptide Y may be under the control of HDAC [263]. Neuropeptide Y becomes over-expressed by recurrent seizures and represents a potent endogenous anticonvulsant [264]. Thus, down-regulation of HDACs may lead to an anticonvulsive effect by increasing neuropeptide $\mathrm{Y}$ expression in the same way as their inhibition by treatment with VPA. HDACIs may have other beneficial effects in epilepsy. Altered gene expression within hippocampal neurons is believed to induce disturbed neurogenesis that may be responsible of epilepsy development [265]. It has been reported that seizure-generated granule cells have the potential to interfere with hippocampal function and contribute to cognitive impairment caused by KA-induced seizures within the hippocampal circuitry [266]. VPA administration in rats after KA-induced SE, reduces the aberrant neurogenesis in the hippocampus, and protects the animals from seizure-associated cognitive deficits. This effect of VPA appeared to be mainly mediated by HDAC inhibition with a subsequent normalization of HDAC-dependent gene expression [266].

In addition, VPA blocks neurogenesis and differentiation of hippocampal progenitor cells in vivo with corresponding increases in histone acetylation [267]. The anticonvulsant and neuroprotective effects of VPA but also of SAHA treatment were also reported after SE [268]. VPA is neuroprotective after chemically induced seizures but also in a rat model of epilepsy, due to electrical stimulation of the basal amygdala [113, 269].Another study found that VPA 
treatment could significantly reduce seizure-induced expression of $c$-fos and $c$-Jun, reinforcing the idea that VPA belongs to a class of antiepileptic drugs that normalizes the expression of seizure-induced genes [270].

HDACI-mediated neuroprotection and stabilization of existing brain circuitry could be a possible mechanism for preventing the spread or progression of epilepsy, and limiting the accompanying cognitive deficits that result from poorly controlled seizures in epileptic patients. The efficacy of HDACIs in epilepsy can be due to their ability to enhance the survival of neurons in existing circuits that might otherwise succumb to excitotoxic cell death due to hyperexcitation and the resulting ionic imbalances.

Despite their proven neuroprotective effects in epilepsy and other brain diseases, VPA and other HDACIs are nonspecific drugs and can cause changes in the state of other epigenetic factors including global DNA demethylation [271, 272], resulting in cell death. Therefore, there is an urgent need in the future to develop new HDAC inhibitors with greatly enhanced specificity and reduced toxicity in order to facilitate their evaluation as potential novel therapeutic agents.

Table 3. Epigenetic modifications in experimental epilepsy models and human epilepsy.

\begin{tabular}{|c|c|c|c|c|}
\hline $\begin{array}{l}\text { Epilepsy } \\
\text { Animal models }\end{array}$ & $\begin{array}{l}\text { Brain region } \\
\text { involved }\end{array}$ & Epigenetic modifications & Affected gene & Refs \\
\hline $\begin{array}{l}\text { Model of pilocarpine- } \\
\text { induced SE }\end{array}$ & Hippocampus & $\begin{array}{l}\downarrow / \uparrow \mathrm{H} 4 \text { acetylation } \\
\uparrow \mathrm{H} 3 \text { phosphorylation } \\
\text { CREB-TF }\end{array}$ & $\begin{array}{l}\downarrow / \uparrow B D N F \\
\downarrow G l u R 2 \\
\uparrow \mathrm{c}-\text { fos }\end{array}$ & $\begin{array}{l}{[226]} \\
{[227]} \\
{[249]}\end{array}$ \\
\hline $\begin{array}{l}\text { Model of kainate-induced } \\
\text { SE }\end{array}$ & Hippocampus & $\begin{array}{l}\uparrow \mathrm{H} 3 \text { phosphorylation } \\
\uparrow / \downarrow \text { H4 acetylation } \\
\uparrow \mathrm{NRSF} / \mathrm{REST}-\mathrm{TF} \\
\mathrm{NF}-\kappa \mathrm{B}-\mathrm{TF}\end{array}$ & $\begin{array}{l}\uparrow \mathrm{c}-f o s \\
\uparrow \mathrm{c}-\mathrm{jun} \\
\uparrow \mathrm{CBP} \\
\downarrow \mathrm{HCN} 1 \\
\downarrow / \uparrow \text { BDNF } \\
\downarrow \text { GluR2 }\end{array}$ & $\begin{array}{l}{[227]} \\
{[229]} \\
{[239]} \\
{[266]}\end{array}$ \\
\hline $\begin{array}{l}\text { Electrically- induced } \\
\text { seizures (ECS) }\end{array}$ & $\begin{array}{l}\text { Hippocampus } \\
\text { Frontal cortex }\end{array}$ & $\begin{array}{l}\downarrow / \uparrow \mathrm{H} 4 \text { acetylation } \\
\downarrow / \uparrow \mathrm{H} 3 \text { acetylation } \\
\text { CREB-TF }\end{array}$ & $\begin{array}{l}\downarrow / \uparrow \mathrm{c}-f o s \\
\downarrow / \uparrow \mathrm{CREB} \\
\downarrow / \uparrow B D N F\end{array}$ & $\begin{array}{l}\text { [228, } \\
273]\end{array}$ \\
\hline Electrical kindling & Hippocampus & NRSF/REST-TF & $\begin{array}{l}\downarrow / \uparrow B D N F \\
\downarrow / \uparrow \operatorname{TrkB}\end{array}$ & [274] \\
\hline $\begin{array}{l}\text { Human TLE and } \\
\text { pilocarpine-induced } \\
\text { seizures }\end{array}$ & $\begin{array}{l}\text { Neocortex } \\
\text { Hippocampus }\end{array}$ & $\uparrow \mathrm{HDAC} 2$ & $\downarrow$ Reelin & [242] \\
\hline \multicolumn{5}{|c|}{$\begin{array}{l}\text { Abbreviations: CREB, cAMP response element; TF, transcription factor; BDNF, brain-derived neurotrophic factor; } \\
\text { GluR2, glutamate receptor } 2 ; \text { - c-fos, NRSF, neuron-restrictive silencer factor; REST, RE1-silencing transcription factor; } \\
N F-\kappa B \text {, nuclear factor kappa B; CBP, CRE-binding protein; HCN1, potassium/sodium hyperpolarization-activated } \\
\text { cyclic nucleotide-gated channel } 1 ; E C S \text {, electroconvulsive seizure; TrkB, tropomyosin-related kinase B; TLE, Temporal } \\
\text { lobe epilepsy; SE, status epilepticus. }\end{array}$} \\
\hline
\end{tabular}

\section{Conclusions}

Epigenetic changes and their role in a variety of human diseases constitutes an important emerging field of research that will help us to better understand the pathophysiology and treatment of brain disorders, including epilepsy. Recent evidence demonstrates that epilepsy is characterized not only by genetic predisposition and environmental insults but also by epigenetic mechanisms. Alterations not only in transcription, but also epigenetic mechanisms are involved in the pathogenesis of human epilepsy and in the process of epileptogenesis. In particular, chromatin histone modifications are 
seen as an important component of the epigenetic changes associated with epilepsy and may thus represent potential therapeutic targets.

This review provides an overview of the role of HDACs in experimental and human epilepsy and reflects on what functional interventions targeting this important protein family can tell us about the role of epigenetics in the pathogenesis of epilepsy and their potential effectiveness for epilepsy therapeutics. HDACs epigenetically play an important role in controlling neuronal functions, probably by regulating the expression and function of genes (e.g. different classes of ion channels and receptors) and gene networks that regulate the intrinsic excitability and synaptic connectivity of individual neurons and of neural networks.

Several studies have indicated changes in the acetylation state of specific promoters of genes presumably related to epileptogenesis. Seizure induction can trigger a myriad of gene upregulations, which could in turn, be regulated by histone modifications, and are now thought to contribute to the development of epilepsy. Moreover, in parallel (as in cancer), epigenetic modifications can affect multidrug trasporters and induce pharmacoresistence in epilepsy. The histone modifications might also be useful as early biomarker indicators of epileptic disease, and thus be targeted with epigenetic drugs such as HDACIs already clinically approved for treating patients with cancer and autoimmune disorders, or with new preclinical drugs that more selectively target histone deacetylase. Indeed, targeted epigenetics offers a potentially powerful strategy for blocking the epileptogenic process and for remodeling neural networks whose balance between excitation and inhibition is altered in epilepsy.

The beneficial effects of HDACI have been reported in preclinical models of epilepsy and other neurological diseases. The realization of these models with a focus on translational therapy in clinics has not however, been completely achieved. Furthermore, lack of understanding of HDAC function in neurons and the CNS in general, is a major reason for this impediment. Thus, additional epigenetic studies are necessary to better understand the contribution of HDAC function to epilepsy and epileptogenic process, and to improve treatment or prevention of this pathology.

Finally, it is worth commenting that most of the currently used HDACIs act non-specifically and target several classes of HDACs and thus, such treatments in a clinical setting, face the risk of undesired side effects, not only in target tissues, but also whole body-wide. A few isoform-specific HDACIs are however, now available for testing, but additional compounds, including both isoform-specific and nonspecific drugs, need to be developed. Unsolved problems include the development of drugs that have the ability to penetrate the BBB and ameliorate neuronal death with minimal toxicity. The BBB permeability and cytotoxic profiles of existing HDACIs also require more critical evaluations. Despite the fact that research in this area is still in its infancy, HDAC inhibition is a promising new avenue for therapeutic intervention in neurological disorders such as epilepsy. In order to develop more potent and more selective epigenetic treatments against epilepsy, a better understanding of the epigenetic machinery is thus required.

\section{Conflict of Interest}

The authors declare that this article content has no conflict of interest.

\section{Acknowledgements}

Declared none. 


\section{References}

[1] Kwan P, Schachter SC, Brodie MJ. Drug-resistant epilepsy. N Engl J Med, 2011; 365: 919-26.

[2] Loscher W, Brandt C. Prevention or modification of epileptogenesis after brain insults: experimental approaches and translational research. Pharmacol Rev, 2010; 62: 668-700.

[3] Rakhade SN, Jensen FE. Epileptogenesis in the immature brain: emerging mechanisms. Nat Rev Neurol, 2009; 5: 380-91.

[4] Pitkanen A, Lukasiuk K, Dudek FE, Staley KJ. Epileptogenesis. Cold Spring Harb Perspect Med, 2015 ; 5.

[5] Pitkanen A, Lukasiuk K. Mechanisms of epileptogenesis and potential treatment targets. Lancet Neurol, 2011; 10: $173-86$.

[6] Dudek FE, Hellier JL, Williams PA, Ferraro DJ, Staley KJ. The course of cellular alterations associated with the development of spontaneous seizures after status epilepticus. Prog Brain Res, 2002; 135: 53-65.

[7] Pitkanen A, Lukasiuk K. Molecular and cellular basis of epileptogenesis in symptomatic epilepsy. Epilepsy Behav, 2009; 14 Suppl 1: 16-25.

[8] Vezzani A, French J, Bartfai T, Baram TZ. The role of inflammation in epilepsy. Nat Rev Neurol, 2011; 7: 31-

40.

[9] Greenberg DA, Pal DK. The state of the art in the genetic analysis of the epilepsies. Curr Neurol Neurosci Rep, 2007; 7: 320-8.

[10] Andrade DM. Genetic basis in epilepsies caused by malformations of cortical development and in those with structurally normal brain. Hum Genet, 2009; 126: 173-93.

[11] Qureshi IA, Mehler MF. Epigenetic mechanisms underlying human epileptic disorders and the process of epileptogenesis. Neurobiol Dis, 2010; 39: 53-60.

[12] Pulido Fontes L, Quesada Jimenez P, Mendioroz Iriarte M. Epigenetics and epilepsy. Neurologia, 2015; 30: 111-8.

[13] Henshall DC, Kobow K. Epigenetics and Epilepsy. Cold Spring Harb Perspect Med, $2015 ; 5$.

[14] Lubin FD. Epileptogenesis: can the science of epigenetics give us answers? Epilepsy Curr, 2012; 12: 105-10.

[15] Graff J, Kim D, Dobbin MM, Tsai LH. Epigenetic regulation of gene expression in physiological and pathological brain processes. Physiol Rev, 2011; 91: 603-49.

[16] Jakovcevski M, Akbarian S. Epigenetic mechanisms in neurological disease. Nat Med, 2012; 18: $1194-204$.

[17] Kobow K, Blumcke I. The emerging role of DNA methylation in epileptogenesis. Epilepsia, 2012; 53 Suppl 9: 11-20.

[18] Kobow K, Jeske I, Hildebrandt M, Hauke J, Hahnen E, Buslei R, Buchfelder M, Weigel D, Stefan H, Kasper B, Pauli E, Blumcke I. Increased reelin promoter methylation is associated with granule cell dispersion in human temporal lobe epilepsy. J Neuropathol Exp Neurol, 2009; 68: 356-64.

[19] Kobow K, El-Osta A, Blumcke I. The methylation hypothesis of pharmacoresistance in epilepsy. Epilepsia, 2013; 54 Suppl 2: 41-7.

[20] Roopra A, Dingledine R, Hsieh J. Epigenetics and epilepsy. Epilepsia, 2012; 53 Suppl 9: 2-10.

[21] Ravi B, Kannan M. Epigenetics in the nervous system: An overview of its essential role. Indian J Hum Genet, 2013; 19: 384-91.

[22] Mehler MF. Epigenetics and the nervous system. Ann Neurol, 2008; 64: 602-17.

[23] Falkenberg KJ, Johnstone RW. Histone deacetylases and their inhibitors in cancer, neurological diseases and immune disorders. Nat Rev Drug Discov, 2014; 13: 673-91.

[24] Zhang H, Shang YP, Chen HY, Li J. Histone deacetylases function as novel potential therapeutic targets for cancer. Hepatol Res, 2016.

[25] Kazantsev AG, Thompson LM. Therapeutic application of histone deacetylase inhibitors for central nervous system disorders. Nat Rev Drug Discov, 2008; 7: 854-68.

[26] Kouzarides T. Chromatin modifications and their function. Cell, 2007; 128: 693-705.

[27] Strahl BD, Allis CD. The language of covalent histone modifications. Nature, 2000; 403: 41-5.

[28] Jenuwein T, Allis CD. Translating the histone code. Science, 2001; 293: 1074-80.

[29] Bannister AJ, Kouzarides T. Regulation of chromatin by histone modifications. Cell Res, 2011; 21: 381-95.

[30] Davie JR, Spencer VA. Signal transduction pathways and the modification of chromatin structure. Prog Nucleic Acid Res Mol Biol, 2001; 65: 299-340.

[31] Smith BC, Denu JM. Chemical mechanisms of histone lysine and arginine modifications. Biochim Biophys Acta, 2009; 1789: 45-57.

[32] Shahbazian MD, Grunstein M. Functions of site-specific histone acetylation and deacetylation. Annu Rev Biochem, 2007; 76: 75-100.

[33] Kimura A, Matsubara K, Horikoshi M. A decade of histone acetylation: marking eukaryotic chromosomes with specific codes. J Biochem, 2005; 138: 647-62.

[34] Fischle W, Wang Y, Allis CD. Histone and chromatin cross-talk. Curr Opin Cell Biol, 2003; 15: $172-83$.

[35] Xu WS, Parmigiani RB, Marks PA. Histone deacetylase inhibitors: molecular mechanisms of action. Oncogene, 2007; 26: 5541-52. 
[36] Haberland M, Montgomery RL, Olson EN. The many roles of histone deacetylases in development and physiology: implications for disease and therapy. Nat Rev Genet, 2009; 10: 32-42.

[37] Cress WD, Seto E. Histone deacetylases, transcriptional control, and cancer. J Cell Physiol, 2000; $184:$ 1-16.

[38] Saha RN, Pahan K. HATs and HDACs in neurodegeneration: a tale of disconcerted acetylation homeostasis. Cell Death Differ, 2006; 13: 539-50.

[39] Di Gennaro E, Bruzzese F, Caraglia M, Abruzzese A, Budillon A. Acetylation of proteins as novel target for antitumor therapy: review article. Amino Acids, 2004; 26: 435-41.

[40] Barneda-Zahonero B, Parra M. Histone deacetylases and cancer. Mol Oncol, 2012; 6: 579-89.

[41] Rutten BP, Mill J. Epigenetic mediation of environmental influences in major psychotic disorders. Schizophr Bull, 2009; 35: 1045-56.

[42] Lu Q, Hutchins AE, Doyle CM, Lundblad JR, Kwok RP. Acetylation of cAMP-responsive element-binding protein (CREB) by CREB-binding protein enhances CREB-dependent transcription. J Biol Chem, 2003; 278 : 15727-34. [43] de Ruijter AJ, van Gennip AH, Caron HN, Kemp S, van Kuilenburg AB. Histone deacetylases (HDACs): characterization of the classical HDAC family. Biochem J, 2003; 370: 737-49.

[44] Seto E, Yoshida M. Erasers of histone acetylation: the histone deacetylase enzymes. Cold Spring Harb Perspect Biol, 2014; 6: a018713.

[45] Delcuve GP, Khan DH, Davie JR. Roles of histone deacetylases in epigenetic regulation: emerging paradigms from studies with inhibitors. Clin Epigenetics, 2012; 4: 5.

[46] Hildmann C, Riester D, Schwienhorst A. Histone deacetylases--an important class of cellular regulators with a variety of functions. Appl Microbiol Biotechnol, 2007; 75: 487-97.

[47] Haigis MC, Sinclair DA. Mammalian sirtuins: biological insights and disease relevance. Annu Rev Pathol, 2010; 5: 253-95.

[48] Blander G, Guarente L. The Sir2 family of protein deacetylases. Annu Rev Biochem, 2004; 73: 417-35.

[49] Denu JM. The Sir 2 family of protein deacetylases. Curr Opin Chem Biol, 2005; 9: 431-40.

[50] Smith BC, Hallows WC, Denu JM. Mechanisms and molecular probes of sirtuins. Chem Biol, 2008; 15: $1002-$

13.

[51] Reichert N, Choukrallah MA, Matthias P. Multiple roles of class I HDACs in proliferation, differentiation, and development. Cell Mol Life Sci, 2012; 69: 2173-87.

[52] Martin M, Kettmann R, Dequiedt F. Class IIa histone deacetylases: regulating the regulators. Oncogene, 2007; 26: $5450-67$.

[53] Morrison BE, Majdzadeh N, D'Mello SR. Histone deacetylases: focus on the nervous system. Cell Mol Life Sci, 2007; 64: 2258-69.

[54] Lardenoije R, Iatrou A, Kenis G, Kompotis K, Steinbusch HW, Mastroeni D, Coleman P, Lemere CA, Hof PR, van den Hove DL, Rutten BP. The epigenetics of aging and neurodegeneration. Prog Neurobiol, 2015; 131: 21 -64.

[55] Ocker M. Deacetylase inhibitors - focus on non-histone targets and effects. World J Biol Chem, 2010; 1: 5561.

[56] Glozak MA, Sengupta N, Zhang X, Seto E. Acetylation and deacetylation of non-histone proteins. Gene, 2005; 363: $15-23$.

[57] Spange S, Wagner T, Heinzel T, Kramer OH. Acetylation of non-histone proteins modulates cellular signalling at multiple levels. Int J Biochem Cell Biol, 2009; 41: 185-98.

[58] Broide RS, Redwine JM, Aftahi N, Young W, Bloom FE, Winrow CJ. Distribution of histone deacetylases 111 in the rat brain. J Mol Neurosci, 2007; 31: 47-58.

[59] Graff J, Tsai LH. The potential of HDAC inhibitors as cognitive enhancers. Annu Rev Pharmacol Toxicol, 2013; 53: 311-30.

[60] Kim MS, Akhtar MW, Adachi M, Mahgoub M, Bassel-Duby R, Kavalali ET, Olson EN, Monteggia LM. An essential role for histone deacetylase 4 in synaptic plasticity and memory formation. J Neurosci, 2012; 32: 10879-86.

[61] Morris MJ, Karra AS, Monteggia LM. Histone deacetylases govern cellular mechanisms underlying behavioral and synaptic plasticity in the developing and adult brain. Behav Pharmacol, 2010; 21: 409-19.

[62] Abel T, Zukin RS. Epigenetic targets of HDAC inhibition in neurodegenerative and psychiatric disorders. Curr Opin Pharmacol, 2008; 8: 57-64.

[63] Machado-Vieira R, Ibrahim L, Zarate CA, Jr. Histone deacetylases and mood disorders: epigenetic programming in gene-environment interactions. CNS Neurosci Ther, 2011; 17: 699-704.

[64] Penney J, Tsai LH. Histone deacetylases in memory and cognition. Sci Signal, 2014; 7: re12.

[65] Mahgoub M, Monteggia LM. A role for histone deacetylases in the cellular and behavioral mechanisms underlying learning and memory. Learn Mem, 2014; 21: 564-8.

[66] Volmar C-H, Wahlestedt Claes. Histone deacetylases (HDACs) and brain function. Neuroepigenetics 2015; 1: 20-27.

[67] Sun J, Sun J, Ming GL, Song H. Epigenetic regulation of neurogenesis in the adult mammalian brain. Eur J Neurosci, 2011; 33: 1087-93. 
75.

[69] Marks PA. Histone deacetylase inhibitors: a chemical genetics approach to understanding cellular functions. Biochim Biophys Acta, 2010; 1799: 717-25.

[70] Lopez-Atalaya JP, Ito S, Valor LM, Benito E, Barco A. Genomic targets, and histone acetylation and gene expression profiling of neural HDAC inhibition. Nucleic Acids Res, 2013; 41: 8072-84.

[71] Marks PA, Dokmanovic M. Histone deacetylase inhibitors: discovery and development as anticancer agents. Expert Opin Investig Drugs, 2005; 14: 1497-511.

[72] Marks PA, Xu WS. Histone deacetylase inhibitors: Potential in cancer therapy. J Cell Biochem, 2009; 107: $600-8$.

[73] Bolden JE, Peart MJ, Johnstone RW. Anticancer activities of histone deacetylase inhibitors. Nat Rev Drug Discov, 2006; 5: 769-84.

[74] Marks PA. The clinical development of histone deacetylase inhibitors as targeted anticancer drugs. Expert Opin Investig Drugs, 2010; 19: 1049-66.

[75] Wagner JM, Hackanson B, Lubbert M, Jung M. Histone deacetylase (HDAC) inhibitors in recent clinical trials for cancer therapy. Clin Epigenetics, 2010; 1: 117-136.

[76] Dickinson M, Johnstone RW, Prince HM. Histone deacetylase inhibitors: potential targets responsible for their anti-cancer effect. Invest New Drugs, 2010; 28 Suppl 1: S3-20.

[77] Chuang DM, Leng Y, Marinova Z, Kim HJ, Chiu CT. Multiple roles of HDAC inhibition in neurodegenerative conditions. Trends Neurosci, 2009; 32: 591-601.

[78] Hahnen E, Hauke J, Trankle C, Eyupoglu IY, Wirth B, Blumcke I. Histone deacetylase inhibitors: possible implications for neurodegenerative disorders. Expert Opin Investig Drugs, 2008; 17: 169-84.

[79] Fischer A, Sananbenesi F, Mungenast A, Tsai LH. Targeting the correct HDAC(s) to treat cognitive disorders. Trends Pharmacol Sci, 2010; 31: 605-17.

[80] Qiu X, Xiao X, Li N, Li Y. Histone deacetylases inhibitors (HDACis) as novel therapeutic application in various clinical diseases. Prog Neuropsychopharmacol Biol Psychiatry, 2017; 72: 60-72.

[81] Grayson DR, Kundakovic M, Sharma RP. Is there a future for histone deacetylase inhibitors in the pharmacotherapy of psychiatric disorders? Mol Pharmacol, 2010; 77: 126-35.

[82] Fuchikami M, Yamamoto S, Morinobu S, Okada S, Yamawaki Y, Yamawaki S. The potential use of histone deacetylase inhibitors in the treatment of depression. Prog Neuropsychopharmacol Biol Psychiatry, 2016; 64: 320-4.

[83] Covington HE, 3rd, Maze I, LaPlant QC, Vialou VF, Ohnishi YN, Berton O, Fass DM, Renthal W, Rush AJ, 3rd, Wu EY, Ghose S, Krishnan V, Russo SJ, Tamminga C, Haggarty SJ, Nestler EJ. Antidepressant actions of histone deacetylase inhibitors. J Neurosci, 2009; 29: 11451-60.

[84] Dokmanovic M, Clarke C, Marks PA. Histone deacetylase inhibitors: overview and perspectives. Mol Cancer Res, 2007; 5: 981-9.

[85] Spiegel S, Milstien S, Grant S. Endogenous modulators and pharmacological inhibitors of histone deacetylases in cancer therapy. Oncogene, 2012; 31: 537-51.

[86] Duvic M, Talpur R, Ni X, Zhang C, Hazarika P, Kelly C, Chiao JH, Reilly JF, Ricker JL, Richon VM, Frankel SR. Phase 2 trial of oral vorinostat (suberoylanilide hydroxamic acid, SAHA) for refractory cutaneous T-cell lymphoma (CTCL). Blood, 2007; 109: 31-9.

[87] Hsing CH, Hung SK, Chen YC, Wei TS, Sun DP, Wang JJ, Yeh CH. Histone Deacetylase Inhibitor Trichostatin A Ameliorated Endotoxin-Induced Neuroinflammation and Cognitive Dysfunction. Mediators Inflamm, 2015; 2015: 163140 .

[88] Fleiss B, Nilsson MK, Blomgren K, Mallard C. Neuroprotection by the histone deacetylase inhibitor trichostatin A in a model of lipopolysaccharide-sensitised neonatal hypoxic-ischaemic brain injury. $\mathrm{J}$ Neuroinflammation, 2012; 9: 70.

[89] Kim HJ, Rowe M, Ren M, Hong JS, Chen PS, Chuang DM. Histone deacetylase inhibitors exhibit antiinflammatory and neuroprotective effects in a rat permanent ischemic model of stroke: multiple mechanisms of action. $\mathbf{J}$ Pharmacol Exp Ther, 2007; 321: 892-901.

[90] Frye R, Myers M, Axelrod KC, Ness EA, Piekarz RL, Bates SE, Booher S. Romidepsin: a new drug for the treatment of cutaneous T-cell lymphoma. Clin J Oncol Nurs, 2012; 16: 195-204.

[91] Piekarz RL, Frye R, Prince HM, Kirschbaum MH, Zain J, Allen SL, Jaffe ES, Ling A, Turner M, Peer CJ, Figg WD, Steinberg SM, Smith S, Joske D, Lewis I, Hutchins L, Craig M, Fojo AT, Wright JJ, Bates SE. Phase 2 trial of romidepsin in patients with peripheral T-cell lymphoma. Blood, 2011; 117: 5827-34.

[92] Phiel CJ, Zhang F, Huang EY, Guenther MG, Lazar MA, Klein PS. Histone deacetylase is a direct target of valproic acid, a potent anticonvulsant, mood stabilizer, and teratogen. J Biol Chem, 2001; 276: 36734-41.

[93] Perucca E. Pharmacological and therapeutic properties of valproate: a summary after 35 years of clinical experience. CNS Drugs, 2002; 16: 695-714.

[94] Loscher W. Basic pharmacology of valproate: a review after 35 years of clinical use for the treatment of epilepsy. CNS Drugs, 2002; 16: 669-94. 
[95] Gottlicher M. Valproic acid: an old drug newly discovered as inhibitor of histone deacetylases. Ann Hematol, 2004; 83 Suppl 1: S91-2.

[96] Johannessen CU. Mechanisms of action of valproate: a commentatory. Neurochem Int, 2000; 37: 103-10.

[97] Haddad PM, Das A, Ashfaq M, Wieck A. A review of valproate in psychiatric practice. Expert Opin Drug Metab Toxicol, 2009; 5: 539-51.

[98] Rogawski MA, Loscher W. The neurobiology of antiepileptic drugs for the treatment of nonepileptic conditions. Nat Med, 2004; 10: 685-92.

[99] Dash PK, Orsi SA, Zhang M, Grill RJ, Pati S, Zhao J, Moore AN. Valproate administered after traumatic brain injury provides neuroprotection and improves cognitive function in rats. PLoS One, 2010; 5: e11383.

[100] Lee JY, Kim HS, Choi HY, Oh TH, Ju BG, Yune TY. Valproic acid attenuates blood-spinal cord barrier disruption by inhibiting matrix metalloprotease-9 activity and improves functional recovery after spinal cord injury. $\mathrm{J}$ Neurochem, 2012; 121: 818-29.

[101] Yu SH, Cho DC, Kim KT, Nam KH, Cho HJ, Sung JK. The neuroprotective effect of treatment of valproic Acid in acute spinal cord injury. J Korean Neurosurg Soc, 2012; 51: 191-8.

[102] Xuan A, Long D, Li J, Ji W, Hong L, Zhang M, Zhang W. Neuroprotective effects of valproic acid following transient global ischemia in rats. Life Sci, 2012; 90: 463-8.

[103] Harrison IF, Dexter DT. Epigenetic targeting of histone deacetylase: therapeutic potential in Parkinson's disease? Pharmacol Ther, 2013; 140: 34-52.

[104] Kilgore M, Miller CA, Fass DM, Hennig KM, Haggarty SJ, Sweatt JD, Rumbaugh G. Inhibitors of class 1 histone deacetylases reverse contextual memory deficits in a mouse model of Alzheimer's disease. Neuropsychopharmacology, 2010; 35: 870-80.

[105] Qing H, He G, Ly PT, Fox CJ, Staufenbiel M, Cai F, Zhang Z, Wei S, Sun X, Chen CH, Zhou W, Wang K, Song W. Valproic acid inhibits Abeta production, neuritic plaque formation, and behavioral deficits in Alzheimer's disease mouse models. J Exp Med, 2008; 205: 2781-9.

[106] Hashimoto R, Hough C, Nakazawa T, Yamamoto T, Chuang DM. Lithium protection against glutamate excitotoxicity in rat cerebral cortical neurons: involvement of NMDA receptor inhibition possibly by decreasing NR2B tyrosine phosphorylation. J Neurochem, 2002; 80: 589-97.

[107] Vajda FJ. Valproate and neuroprotection. J Clin Neurosci, 2002; 9: 508-14.

[108] Rekling JC. Neuroprotective effects of anticonvulsants in rat hippocampal slice cultures exposed to oxygen/glucose deprivation. Neurosci Lett, 2003; 335: 167-70.

[109] Mohammed TA, Holen KD, Jaskula-Sztul R, Mulkerin D, Lubner SJ, Schelman WR, Eickhoff J, Chen H, Loconte NK. A pilot phase II study of valproic acid for treatment of low-grade neuroendocrine carcinoma. Oncologist, 2011; 16: 835-43.

[110] Papi A, Ferreri AM, Rocchi P, Guerra F, Orlandi M. Epigenetic modifiers as anticancer drugs: effectiveness of valproic acid in neural crest-derived tumor cells. Anticancer Res, 2010; 30: 535-40.

[111] Gurvich N, Tsygankova OM, Meinkoth JL, Klein PS. Histone deacetylase is a target of valproic acid-mediated cellular differentiation. Cancer Res, 2004; 64: 1079-86.

[112] Gottlicher M, Minucci S, Zhu P, Kramer OH, Schimpf A, Giavara S, Sleeman JP, Lo Coco F, Nervi C, Pelicci PG, Heinzel T. Valproic acid defines a novel class of HDAC inhibitors inducing differentiation of transformed cells. EMBO J, 2001; 20: 6969-78.

[113] Monti B, Polazzi E, Contestabile A. Biochemical, molecular and epigenetic mechanisms of valproic acid neuroprotection. Curr Mol Pharmacol, 2009; 2: 95-109.

[114] Kostrouchova M, Kostrouch Z, Kostrouchova M. Valproic acid, a molecular lead to multiple regulatory pathways. Folia Biol (Praha), 2007; 53: 37-49.

[115] Tomson T, Battino D, Perucca E. Valproic acid after five decades of use in epilepsy: time to reconsider the indications of a time-honoured drug. Lancet Neurol, 2015.

[116] Davie JR. Inhibition of histone deacetylase activity by butyrate. J Nutr, 2003; 133: 2485S-2493S.

[117] Vecsey CG, Hawk JD, Lattal KM, Stein JM, Fabian SA, Attner MA, Cabrera SM, McDonough CB, Brindle PK, Abel T, Wood MA. Histone deacetylase inhibitors enhance memory and synaptic plasticity via CREB:CBPdependent transcriptional activation. J Neurosci, 2007; 27: 6128-40.

[118] Ferrante RJ, Kubilus JK, Lee J, Ryu H, Beesen A, Zucker B, Smith K, Kowall NW, Ratan RR, Luthi-Carter R, Hersch SM. Histone deacetylase inhibition by sodium butyrate chemotherapy ameliorates the neurodegenerative phenotype in Huntington's disease mice. J Neurosci, 2003; 23: 9418-27.

[119] Chou AH, Chen SY, Yeh TH, Weng YH, Wang HL. HDAC inhibitor sodium butyrate reverses transcriptional downregulation and ameliorates ataxic symptoms in a transgenic mouse model of SCA3. Neurobiol Dis, 2011; 41: 4818 .

[120] Sharma S, Taliyan R, Singh S. Beneficial effects of sodium butyrate in 6-OHDA induced neurotoxicity and behavioral abnormalities: Modulation of histone deacetylase activity. Behav Brain Res, 2015; 291: 306-14. 
[121] Govindarajan N, Agis-Balboa RC, Walter J, Sananbenesi F, Fischer A. Sodium butyrate improves memory function in an Alzheimer's disease mouse model when administered at an advanced stage of disease progression. $\mathbf{J}$ Alzheimers Dis, 2011; 26: 187-97.

[122] Kim HJ, Leeds P, Chuang DM. The HDAC inhibitor, sodium butyrate, stimulates neurogenesis in the ischemic brain. J Neurochem, 2009; 110: 1226-40.

[123] Schroeder FA, Lin CL, Crusio WE, Akbarian S. Antidepressant-like effects of the histone deacetylase inhibitor, sodium butyrate, in the mouse. Biol Psychiatry, 2007; 62: 55-64.

[124] Wei Y, Melas PA, Wegener G, Mathe AA, Lavebratt C. Antidepressant-like effect of sodium butyrate is associated with an increase in TET1 and in 5-hydroxymethylation levels in the Bdnf gene. Int J Neuropsychopharmacol, $2014 ; 18$.

[125] Vinolo MA, Rodrigues HG, Nachbar RT, Curi R. Regulation of inflammation by short chain fatty acids. Nutrients, 2011; 3: 858-76.

[126] Murphy SP, Lee RJ, McClean ME, Pemberton HE, Uo T, Morrison RS, Bastian C, Baltan S. MS-275, a class I histone deacetylase inhibitor, protects the p53-deficient mouse against ischemic injury. J Neurochem, 2014; 129: 50915 .

[127] Simonini MV, Camargo LM, Dong E, Maloku E, Veldic M, Costa E, Guidotti A. The benzamide MS-275 is a potent, long-lasting brain region-selective inhibitor of histone deacetylases. Proc Natl Acad Sci U S A, 2006; 103: $1587-92$.

[128] Hess-Stumpp H, Bracker TU, Henderson D, Politz O. MS-275, a potent orally available inhibitor of histone deacetylases--the development of an anticancer agent. Int J Biochem Cell Biol, 2007; 39: 1388-405.

[129] Gangisetty O, Murugan S. Epigenetic Modifications in Neurological Diseases: Natural Products as Epigenetic Modulators a Treatment Strategy. Adv Neurobiol, 2016; 12: 1-25.

[130] Benedetti R, Conte M, Altucci L. Targeting Histone Deacetylases in Diseases: Where Are We? Antioxid Redox Signal, 2015; 23: 99-126.

[131] Levenson JM, Sweatt JD. Epigenetic mechanisms in memory formation. Nat Rev Neurosci, 2005; 6: 108-18.

[132] Villain H, Florian C, Roullet P. HDAC inhibition promotes both initial consolidation and reconsolidation of spatial memory in mice. Sci Rep, 2016; 6: 27015.

[133] Peleg S, Sananbenesi F, Zovoilis A, Burkhardt S, Bahari-Javan S, Agis-Balboa RC, Cota P, Wittnam JL, Gogol-Doering A, Opitz L, Salinas-Riester G, Dettenhofer M, Kang H, Farinelli L, Chen W, Fischer A. Altered histone acetylation is associated with age-dependent memory impairment in mice. Science, 2010; 328: 753-6.

[134] Fischer A, Sananbenesi F, Wang X, Dobbin M, Tsai LH. Recovery of learning and memory is associated with chromatin remodelling. Nature, 2007; 447: 178-82.

[135] Peixoto L, Abel T. The role of histone acetylation in memory formation and cognitive impairments. Neuropsychopharmacology, 2013; 38: 62-76.

[136] Lopez-Atalaya JP, Barco A. Can changes in histone acetylation contribute to memory formation? Trends Genet, 2014; 30: 529-39.

[137] Alarcon JM, Malleret G, Touzani K, Vronskaya S, Ishii S, Kandel ER, Barco A. Chromatin acetylation, memory, and LTP are impaired in CBP+/- mice: a model for the cognitive deficit in Rubinstein-Taybi syndrome and its amelioration. Neuron, 2004; 42: 947-59.

[138] Guan JS, Haggarty SJ, Giacometti E, Dannenberg JH, Joseph N, Gao J, Nieland TJ, Zhou Y, Wang X, Mazitschek R, Bradner JE, DePinho RA, Jaenisch R, Tsai LH. HDAC2 negatively regulates memory formation and synaptic plasticity. Nature, 2009; 459: 55-60.

[139] Montgomery RL, Hsieh J, Barbosa AC, Richardson JA, Olson EN. Histone deacetylases 1 and 2 control the progression of neural precursors to neurons during brain development. Proc Natl Acad Sci U S A, 2009; 106 : 7876-81.

[140] Szyf M. Epigenetics, DNA methylation, and chromatin modifying drugs. Annu Rev Pharmacol Toxicol, 2009; 49: 243-63.

[141] Ganai SA, Ramadoss M, Mahadevan V. Histone Deacetylase (HDAC) Inhibitors - emerging roles in neuronal memory, learning, synaptic plasticity and neural regeneration. Curr Neuropharmacol, 2016; 14: 55-71.

[142] Landgrave-Gomez J, Mercado-Gomez O, Guevara-Guzman R. Epigenetic mechanisms in neurological and neurodegenerative diseases. Front Cell Neurosci, 2015; 9: 58.

[143] D'Mello SR. Histone deacetylases as targets for the treatment of human neurodegenerative diseases. Drug News Perspect, 2009; 22: 513-24.

[144] Rouaux C, Jokic N, Mbebi C, Boutillier S, Loeffler JP, Boutillier AL. Critical loss of CBP/p300 histone acetylase activity by caspase-6 during neurodegeneration. EMBO J, 2003; 22: 6537-49.

[145] Sadri-Vakili G, Bouzou B, Benn CL, Kim MO, Chawla P, Overland RP, Glajch KE, Xia E, Qiu Z, Hersch SM, Clark TW, Yohrling GJ, Cha JH. Histones associated with downregulated genes are hypo-acetylated in Huntington's disease models. Hum Mol Genet, 2007; 16: 1293-306.

[146] Xu K, Dai XL, Huang HC, Jiang ZF. Targeting HDACs: a promising therapy for Alzheimer's disease. Oxid Med Cell Longev, 2011; 2011: 143269. 
[147] Sharma S, Taliyan R. Targeting histone deacetylases: a novel approach in Parkinson's disease. Parkinsons Dis, 2015; $2015: 303294$.

[148] Fischer A. Targeting histone-modifications in Alzheimer's disease. What is the evidence that this is a promising therapeutic avenue? Neuropharmacology, 2014; 80: 95-102.

[149] Ding H, Dolan PJ, Johnson GV. Histone deacetylase 6 interacts with the microtubule-associated protein tau. J Neurochem, 2008; 106: 2119-30.

[150] Lu X, Wang L, Yu C, Yu D, Yu G. Histone Acetylation Modifiers in the Pathogenesis of Alzheimer's Disease. Front Cell Neurosci, 2015; 9: 226.

[151] Didonna A, Opal P. The promise and perils of HDAC inhibitors in neurodegeneration. Ann Clin Transl Neurol, 2015; 2: 79-101.

[152] Yang W, Chauhan A, Mehta S, Mehta P, Gu F, Chauhan V. Trichostatin A increases the levels of plasma gelsolin and amyloid beta-protein in a transgenic mouse model of Alzheimer's disease. Life Sci, 2014; 99: 31-6.

[153] Sharma S, Taliyan R, Ramagiri S. Histone deacetylase inhibitor, trichostatin A, improves learning and memory in high-fat diet-induced cognitive deficits in mice. J Mol Neurosci, 2015; 56: 1-11.

[154] Ben-Menachem E. Lacosamide: an investigational drug for adjunctive treatment of partial-onset seizures. Drugs Today (Barc), 2008; 44: 35-40.

[155] Bang SR, Ambavade SD, Jagdale PG, Adkar PP, Waghmare AB, Ambavade PD. Lacosamide reduces HDAC levels in the brain and improves memory: Potential for treatment of Alzheimer's disease. Pharmacol Biochem Behav, 2015; 134: 65-9.

[156] Sharma S, Taliyan R. Transcriptional dysregulation in Huntington's disease: The role of histone deacetylases. Pharmacol Res, 2015; 100: 157-69.

[157] Pena-Altamira LE, Polazzi E, Monti B. Histone post-translational modifications in Huntington's and Parkinson's diseases. Curr Pharm Des, 2013; 19: 5085-92.

[158] Hogarth P, Lovrecic L, Krainc D. Sodium phenylbutyrate in Huntington's disease: a dose-finding study. Mov Disord, 2007; 22: 1962-4.

[159] Mielcarek M, Benn CL, Franklin SA, Smith DL, Woodman B, Marks PA, Bates GP. SAHA decreases HDAC 2 and 4 levels in vivo and improves molecular phenotypes in the R6/2 mouse model of Huntington's disease. PLoS One, 2011; 6: e27746.

[160] Hockly E, Richon VM, Woodman B, Smith DL, Zhou X, Rosa E, Sathasivam K, Ghazi-Noori S, Mahal A, Lowden PA, Steffan JS, Marsh JL, Thompson LM, Lewis CM, Marks PA, Bates GP. Suberoylanilide hydroxamic acid, a histone deacetylase inhibitor, ameliorates motor deficits in a mouse model of Huntington's disease. Proc Natl Acad Sci U S A, 2003; 100: 2041-6.

[161] Bowles KR, Brooks SP, Dunnett SB, Jones L. Gene expression and behaviour in mouse models of HD. Brain Res Bull, 2012; 88: 276-84.

[162] Zuccato C, Ciammola A, Rigamonti D, Leavitt BR, Goffredo D, Conti L, MacDonald ME, Friedlander RM, Silani V, Hayden MR, Timmusk T, Sipione S, Cattaneo E. Loss of huntingtin-mediated BDNF gene transcription in Huntington's disease. Science, 2001; 293: 493-8.

[163] Thomas EA, Coppola G, Desplats PA, Tang B, Soragni E, Burnett R, Gao F, Fitzgerald KM, Borok JF, Herman D, Geschwind DH, Gottesfeld JM. The HDAC inhibitor $4 \mathrm{~b}$ ameliorates the disease phenotype and transcriptional abnormalities in Huntington's disease transgenic mice. Proc Natl Acad Sci U S A, 2008; 105: 15564-9.

[164] Saft C, Lauter T, Kraus PH, Przuntek H, Andrich JE. Dose-dependent improvement of myoclonic hyperkinesia due to Valproic acid in eight Huntington's Disease patients: a case series. BMC Neurol, 2006; 6: 11.

[165] Choong CJ, Sasaki T, Hayakawa H, Yasuda T, Baba K, Hirata Y, Uesato S, Mochizuki H. A novel histone deacetylase 1 and 2 isoform-specific inhibitor alleviates experimental Parkinson's disease. Neurobiol Aging, 2016; 37: $103-16$

[166] Mai A, Rotili D, Valente S, Kazantsev AG. Histone deacetylase inhibitors and neurodegenerative disorders: holding the promise. Curr Pharm Des, 2009; 15: 3940-57.

[167] Inden M, Kitamura Y, Takeuchi H, Yanagida T, Takata K, Kobayashi Y, Taniguchi T, Yoshimoto K, Kaneko M, Okuma Y, Taira T, Ariga H, Shimohama S. Neurodegeneration of mouse nigrostriatal dopaminergic system induced by repeated oral administration of rotenone is prevented by 4-phenylbutyrate, a chemical chaperone. J Neurochem, 2007; 101: 1491-1504

[168] Kontopoulos E, Parvin JD, Feany MB. Alpha-synuclein acts in the nucleus to inhibit histone acetylation and promote neurotoxicity. Hum Mol Genet, 2006; 15: 3012-23.

[169] Chen PS, Peng GS, Li G, Yang S, Wu X, Wang CC, Wilson B, Lu RB, Gean PW, Chuang DM, Hong JS. Valproate protects dopaminergic neurons in midbrain neuron/glia cultures by stimulating the release of neurotrophic factors from astrocytes. Mol Psychiatry, 2006; 11: 1116-25.

[170] Wu X, Chen PS, Dallas S, Wilson B, Block ML, Wang CC, Kinyamu H, Lu N, Gao X, Leng Y, Chuang DM, Zhang W, Lu RB, Hong JS. Histone deacetylase inhibitors up-regulate astrocyte GDNF and BDNF gene transcription and protect dopaminergic neurons. Int J Neuropsychopharmacol, 2008; 11: 1123-34. 
[171] Figueroa-Romero C, Hur J, Bender DE, Delaney CE, Cataldo MD, Smith AL, Yung R, Ruden DM, Callaghan $\mathrm{BC}$, Feldman EL. Identification of epigenetically altered genes in sporadic amyotrophic lateral sclerosis. PLoS One, 2012; 7: e52672.

[172] Qureshi IA, Mehler MF. Epigenetic mechanisms underlying the pathogenesis of neurogenetic diseases. Neurotherapeutics, 2014; 11: 708-20.

[173] Sugai F, Yamamoto Y, Miyaguchi K, Zhou Z, Sumi H, Hamasaki T, Goto M, Sakoda S. Benefit of valproic acid in suppressing disease progression of ALS model mice. Eur J Neurosci, 2004; 20: 3179-83.

[174] Rouaux C, Panteleeva I, Rene F, Gonzalez de Aguilar JL, Echaniz-Laguna A, Dupuis L, Menger Y, Boutillier AL, Loeffler JP. Sodium valproate exerts neuroprotective effects in vivo through CREB-binding protein-dependent mechanisms but does not improve survival in an amyotrophic lateral sclerosis mouse model. J Neurosci, 2007; 27: 5535-45.

[175] Feng HL, Leng Y, Ma CH, Zhang J, Ren M, Chuang DM. Combined lithium and valproate treatment delays disease onset, reduces neurological deficits and prolongs survival in an amyotrophic lateral sclerosis mouse model. Neuroscience, 2008; 155: 567-72.

[176] Ryu H, Smith K, Camelo SI, Carreras I, Lee J, Iglesias AH, Dangond F, Cormier KA, Cudkowicz ME, Brown RH, Jr., Ferrante RJ. Sodium phenylbutyrate prolongs survival and regulates expression of anti-apoptotic genes in transgenic amyotrophic lateral sclerosis mice. J Neurochem, 2005; 93: 1087-98.

[177] Del Signore SJ, Amante DJ, Kim J, Stack EC, Goodrich S, Cormier K, Smith K, Cudkowicz ME, Ferrante RJ. Combined riluzole and sodium phenylbutyrate therapy in transgenic amyotrophic lateral sclerosis mice. Amyotroph Lateral Scler, 2009; 10: 85-94.

[178] Lunke S, El-Osta A. Applicability of histone deacetylase inhibition for the treatment of spinal muscular atrophy. Neurotherapeutics, 2013; 10: 677-87.

[179] Andreassi C, Angelozzi C, Tiziano FD, Vitali T, De Vincenzi E, Boninsegna A, Villanova M, Bertini E, Pini A, Neri G, Brahe C. Phenylbutyrate increases SMN expression in vitro: relevance for treatment of spinal muscular atrophy. Eur J Hum Genet, 2004; 12: 59-65.

[180] Avila AM, Burnett BG, Taye AA, Gabanella F, Knight MA, Hartenstein P, Cizman Z, Di Prospero NA, Pellizzoni L, Fischbeck KH, Sumner CJ. Trichostatin A increases SMN expression and survival in a mouse model of spinal muscular atrophy. J Clin Invest, 2007; 117: 659-71.

[181] Hahnen E, Eyupoglu IY, Brichta L, Haastert K, Trankle C, Siebzehnrubl FA, Riessland M, Holker I, Claus P, Romstock J, Buslei R, Wirth B, Blumcke I. In vitro and ex vivo evaluation of second-generation histone deacetylase inhibitors for the treatment of spinal muscular atrophy. J Neurochem, 2006; 98: 193-202.

[182] Chang JG, Hsieh-Li HM, Jong YJ, Wang NM, Tsai CH, Li H. Treatment of spinal muscular atrophy by sodium butyrate. Proc Natl Acad Sci U S A, 2001; 98: 9808-13.

[183] Tsai LK, Tsai MS, Lin TB, Hwu WL, Li H. Establishing a standardized therapeutic testing protocol for spinal muscular atrophy. Neurobiol Dis, 2006; 24: 286-95.

[184] Tsai LK, Tsai MS, Ting CH, Li H. Multiple therapeutic effects of valproic acid in spinal muscular atrophy model mice. J Mol Med (Berl), 2008; 86: 1243-54.

[185] Riessland M, Ackermann B, Forster A, Jakubik M, Hauke J, Garbes L, Fritzsche I, Mende Y, Blumcke I, Hahnen E, Wirth B. SAHA ameliorates the SMA phenotype in two mouse models for spinal muscular atrophy. Hum Mol Genet, 2010; 19: 1492-506.

[186] Brichta L, Hofmann Y, Hahnen E, Siebzehnrubl FA, Raschke H, Blumcke I, Eyupoglu IY, Wirth B. Valproic acid increases the SMN2 protein level: a well-known drug as a potential therapy for spinal muscular atrophy. Hum Mol Genet, 2003; 12: 2481-9.

[187] Sumner CJ, Huynh TN, Markowitz JA, Perhac JS, Hill B, Coovert DD, Schussler K, Chen X, Jarecki J, Burghes AH, Taylor JP, Fischbeck KH. Valproic acid increases SMN levels in spinal muscular atrophy patient cells. Ann Neurol, 2003; 54: 647-54.

[188] Riessland M, Brichta L, Hahnen E, Wirth B. The benzamide M344, a novel histone deacetylase inhibitor, significantly increases SMN2 RNA/protein levels in spinal muscular atrophy cells. Hum Genet, 2006; 120: $101-10$.

[189] Brahe C, Vitali T, Tiziano FD, Angelozzi C, Pinto AM, Borgo F, Moscato U, Bertini E, Mercuri E, Neri G. Phenylbutyrate increases SMN gene expression in spinal muscular atrophy patients. Eur J Hum Genet, 2005; 13: $256-9$.

[190] Weihl CC, Connolly AM, Pestronk A. Valproate may improve strength and function in patients with type III/IV spinal muscle atrophy. Neurology, 2006; 67: 500-1.

[191] Rak K, Lechner BD, Schneider C, Drexl H, Sendtner M, Jablonka S. Valproic acid blocks excitability in SMA type I mouse motor neurons. Neurobiol Dis, 2009; 36: 477-87.

[192] Ren M, Leng Y, Jeong M, Leeds PR, Chuang DM. Valproic acid reduces brain damage induced by transient focal cerebral ischemia in rats: potential roles of histone deacetylase inhibition and heat shock protein induction. $\mathbf{J}$ Neurochem, 2004; 89: 1358-67.

[193] Langley B, Brochier C, Rivieccio MA. Targeting histone deacetylases as a multifaceted approach to treat the diverse outcomes of stroke. Stroke, 2009; 40: 2899-905. 
[194] Gibson CL, Murphy SP. Benefits of histone deacetylase inhibitors for acute brain injury: a systematic review of animal studies. J Neurochem, 2010; 115: 806-13.

[195] Faraco G, Pancani T, Formentini L, Mascagni P, Fossati G, Leoni F, Moroni F, Chiarugi A. Pharmacological inhibition of histone deacetylases by suberoylanilide hydroxamic acid specifically alters gene expression and reduces ischemic injury in the mouse brain. Mol Pharmacol, 2006; 70: 1876-84.

[196] Endres M, Meisel A, Biniszkiewicz D, Namura S, Prass K, Ruscher K, Lipski A, Jaenisch R, Moskowitz MA, Dirnagl U. DNA methyltransferase contributes to delayed ischemic brain injury. J Neurosci, 2000; $20: 3175-81$.

[197] Wang B, Zhu X, Kim Y, Li J, Huang S, Saleem S, Li RC, Xu Y, Dore S, Cao W. Histone deacetylase inhibition activates transcription factor Nrf2 and protects against cerebral ischemic damage. Free Radic Biol Med, 2012; 52: 928-36.

[198] Yildirim F, Gertz K, Kronenberg G, Harms C, Fink KB, Meisel A, Endres M. Inhibition of histone deacetylation protects wildtype but not gelsolin-deficient mice from ischemic brain injury. Exp Neurol, 2008; $210: 531$ 42.

[199] Tsankova N, Renthal W, Kumar A, Nestler EJ. Epigenetic regulation in psychiatric disorders. Nat Rev Neurosci, 2007; 8: 355-67.

[200] Tsankova NM, Berton O, Renthal W, Kumar A, Neve RL, Nestler EJ. Sustained hippocampal chromatin regulation in a mouse model of depression and antidepressant action. Nat Neurosci, 2006; 9: 519-25.

[201] Shorter KR, Miller BH. Epigenetic mechanisms in schizophrenia. Prog Biophys Mol Biol, 2015; 118 : 1-7.

[202] Karsli-Ceppioglu S. Epigenetic Mechanisms in Psychiatric Diseases and Epigenetic Therapy. Drug Dev Res, 2016; 77: 407-413.

[203] Weiwer M, Lewis MC, Wagner FF, Holson EB. Therapeutic potential of isoform selective HDAC inhibitors for the treatment of schizophrenia. Future Med Chem, 2013; 5: 1491-508.

[204] Sharma RP, Grayson DR, Gavin DP. Histone deactylase 1 expression is increased in the prefrontal cortex of schizophrenia subjects: analysis of the National Brain Databank microarray collection. Schizophr Res, 2008; 98 : 111 -7.

[205] Hobara T, Uchida S, Otsuki K, Matsubara T, Funato H, Matsuo K, Suetsugi M, Watanabe Y. Altered gene expression of histone deacetylases in mood disorder patients. J Psychiatr Res, 2010; 44: 263-70.

[206] Gavin DP, Kartan S, Chase K, Jayaraman S, Sharma RP. Histone deacetylase inhibitors and candidate gene expression: An in vivo and in vitro approach to studying chromatin remodeling in a clinical population. J Psychiatr Res, 2009; 43: 870-6.

[207] Hasan A, Mitchell A, Schneider A, Halene T, Akbarian S. Epigenetic dysregulation in schizophrenia: molecular and clinical aspects of histone deacetylase inhibitors. Eur Arch Psychiatry Clin Neurosci, 2013; 263 : 273 -84.

[208] Bilang-Bleuel A, Ulbricht S, Chandramohan Y, De Carli S, Droste SK, Reul JM. Psychological stress increases histone $\mathrm{H} 3$ phosphorylation in adult dentate gyrus granule neurons: involvement in a glucocorticoid receptor-dependent behavioural response. Eur J Neurosci, 2005; 22: 1691-700.

[209] Hollis F, Duclot F, Gunjan A, Kabbaj M. Individual differences in the effect of social defeat on anhedonia and histone acetylation in the rat hippocampus. Horm Behav, 2011; 59: 331-7.

[210] Otsuki K, Uchida S, Hobara T, Yamagata H, Watanabe Y. [Epigenetic regulation in depression]. Nihon Shinkei Seishin Yakurigaku Zasshi, 2012; 32: 181-6.

[211] Deutsch SI, Rosse RB, Long KD, Gaskins BL, Burket JA, Mastropaolo J. Sodium butyrate, an epigenetic interventional strategy, attenuates a stress-induced alteration of MK-801's pharmacologic action. Eur Neuropsychopharmacol, 2008; 18: 565-8.

[212] Covington HE, 3rd, Vialou VF, LaPlant Q, Ohnishi YN, Nestler EJ. Hippocampal-dependent antidepressantlike activity of histone deacetylase inhibition. Neurosci Lett, 2011; 493: 122-6.

[213] Bredy TW, Wu H, Crego C, Zellhoefer J, Sun YE, Barad M. Histone modifications around individual BDNF gene promoters in prefrontal cortex are associated with extinction of conditioned fear. Learn Mem, 2007; 14: 268 -76.

[214] Chwang WB, O'Riordan KJ, Levenson JM, Sweatt JD. ERK/MAPK regulates hippocampal histone phosphorylation following contextual fear conditioning. Learn Mem, 2006; 13: 322-8.

[215] Yuan P, Zhou R, Wang Y, Li X, Li J, Chen G, Guitart X, Manji HK. Altered levels of extracellular signalregulated kinase signaling proteins in postmortem frontal cortex of individuals with mood disorders and schizophrenia. J Affect Disord, 2010; 124: 164-9.

[216] Ziemka-Nalecz M, Zalewska T. Neuroprotective effects of histone deacetylase inhibitors in brain ischemia. Acta Neurobiol Exp (Wars), 2014; 74: 383-95.

[217] Berg AT, Berkovic SF, Brodie MJ, Buchhalter J, Cross JH, van Emde Boas W, Engel J, French J, Glauser TA, Mathern GW, Moshe SL, Nordli D, Plouin P, Scheffer IE. Revised terminology and concepts for organization of seizures and epilepsies: report of the ILAE Commission on Classification and Terminology, 2005-2009. Epilepsia, 2010; 51: 676-85.

[218] Catterall WA, Dib-Hajj S, Meisler MH, Pietrobon D. Inherited neuronal ion channelopathies: new windows on complex neurological diseases. J Neurosci, 2008; 28: 11768-77.

[219] Galanopoulou AS, Buckmaster PS, Staley KJ, Moshe SL, Perucca E, Engel J, Jr., Loscher W, Noebels JL, Pitkanen A, Stables J, White HS, O'Brien TJ, Simonato M, American Epilepsy Society Basic Science C, The 
International League Against Epilepsy Working Group On Recommendations For Preclinical Epilepsy Drug D. Identification of new epilepsy treatments: issues in preclinical methodology. Epilepsia, 2012; 53: 571-82.

[220] Grooms SY, Opitz T, Bennett MV, Zukin RS. Status epilepticus decreases glutamate receptor 2 mRNA and protein expression in hippocampal pyramidal cells before neuronal death. Proc Natl Acad Sci U S A, 2000; 97: 3631 -6.

[221] Sanchez RM, Koh S, Rio C, Wang C, Lamperti ED, Sharma D, Corfas G, Jensen FE. Decreased glutamate receptor 2 expression and enhanced epileptogenesis in immature rat hippocampus after perinatal hypoxia-induced seizures. J Neurosci, 2001; 21: 8154-63.

[222] Kokaia M, Ernfors P, Kokaia Z, Elmer E, Jaenisch R, Lindvall O. Suppressed epileptogenesis in BDNF mutant mice. Exp Neurol, 1995; 133: 215-24.

[223] Hwang JY, Aromolaran KA, Zukin RS. Epigenetic mechanisms in stroke and epilepsy. Neuropsychopharmacology, 2013; 38: 167-82.

[224] Kobow K, Blumcke I. Epigenetic mechanisms in epilepsy. Prog Brain Res, 2014; 213: 279-316.

[225] Simonato M. Gene therapy for epilepsy. Epilepsy Behav, 2014; 38: 125-30.

[226] Huang Y, Doherty JJ, Dingledine R. Altered histone acetylation at glutamate receptor 2 and brain-derived neurotrophic factor genes is an early event triggered by status epilepticus. J Neurosci, 2002; 22: 8422-8.

[227] Crosio C, Heitz E, Allis CD, Borrelli E, Sassone-Corsi P. Chromatin remodeling and neuronal response: multiple signaling pathways induce specific histone $\mathrm{H} 3$ modifications and early gene expression in hippocampal neurons. J Cell Sci, 2003; 116: 4905-14.

[228] Tsankova NM, Kumar A, Nestler EJ. Histone modifications at gene promoter regions in rat hippocampus after acute and chronic electroconvulsive seizures. J Neurosci, 2004; 24: 5603-10.

[229] Sng JC, Taniura H, Yoneda Y. Histone modifications in kainate-induced status epilepticus. Eur J Neurosci, 2006; 23: 1269-82.

[230] Ben-Ari Y, Cossart R. Kainate, a double agent that generates seizures: two decades of progress. Trends Neurosci, 2000; 23: 580-7.

[231] Elliott RC, Miles MF, Lowenstein DH. Overlapping microarray profiles of dentate gyrus gene expression during development- and epilepsy-associated neurogenesis and axon outgrowth. J Neurosci, 2003; 23: 2218-27.

[232] Strelkov IS, Davie JR. Ser-10 phosphorylation of histone H3 and immediate early gene expression in oncogene-transformed mouse fibroblasts. Cancer Res, 2002; 62: 75-8.

[233] Barratt MJ, Hazzalin CA, Cano E, Mahadevan LC. Mitogen-stimulated phosphorylation of histone H3 is targeted to a small hyperacetylation-sensitive fraction. Proc Natl Acad Sci U S A, 1994; 91: 4781-5.

[234] Clayton AL, Rose S, Barratt MJ, Mahadevan LC. Phosphoacetylation of histone H3 on c-fos- and c-junassociated nucleosomes upon gene activation. EMBO J, 2000; 19: 3714-26.

[235] Jagirdar R, Drexel M, Kirchmair E, Tasan RO, Sperk G. Rapid changes in expression of class I and IV histone deacetylases during epileptogenesis in mouse models of temporal lobe epilepsy. Exp Neurol, 2015; 273: 92-104.

[236] Jagirdar R, Drexel M, Bukovac A, Tasan RO, Sperk G. Expression of class II HDACs in two mouse models of temporal lobe epilepsy. J Neurochem, 2015.

[237] Simonato M, Zucchini S. Are the neurotrophic factors a suitable therapeutic target for the prevention of epileptogenesis? Epilepsia, 2010; 51 Suppl 3: 48-51.

[238] Simonato M, Bregola G, Armellin M, Del Piccolo P, Rodi D, Zucchini S, Tongiorgi E. Dendritic targeting of mRNAs for plasticity genes in experimental models of temporal lobe epilepsy. Epilepsia, 2002; 43 Suppl 5: $153-8$.

[239] Taniura H, Sng JC, Yoneda Y. Histone modifications in status epilepticus induced by kainate. Histol Histopathol, 2006; 21: 785-91.

[240] Sng JC, Taniura H, Yoneda Y. Inhibition of histone deacetylation by trichostatin A intensifies the transcriptions of neuronal c-fos and c-jun genes after kainate stimulation. Neurosci Lett, 2005; 386: 150-5.

[241] Mori T, Wakabayashi T, Ogawa H, Hirahara Y, Koike T, Yamada H. Increased histone H3 phosphorylation in neurons in specific brain structures after induction of status epilepticus in mice. PLoS One, 2013; 8: e77710.

[242] Huang Y, Zhao F, Wang L, Yin H, Zhou C, Wang X. Increased expression of histone deacetylases 2 in temporal lobe epilepsy: a study of epileptic patients and rat models. Synapse, 2012; 66: 151-9.

[243] Thomson S, Clayton AL, Mahadevan LC. Independent dynamic regulation of histone phosphorylation and acetylation during immediate-early gene induction. Mol Cell, 2001; 8: 1231-41.

[244] Scharfman HE, Goodman JH, Sollas AL. Actions of brain-derived neurotrophic factor in slices from rats with spontaneous seizures and mossy fiber sprouting in the dentate gyrus. J Neurosci, 1999; 19: 5619-31.

[245] Nateri AS, Raivich G, Gebhardt C, Da Costa C, Naumann H, Vreugdenhil M, Makwana M, Brandner S, Adams RH, Jefferys JG, Kann O, Behrens A. ERK activation causes epilepsy by stimulating NMDA receptor activity. EMBO J, 2007; 26: 4891-901.

[246] Beaumont TL, Yao B, Shah A, Kapatos G, Loeb JA. Layer-specific CREB target gene induction in human neocortical epilepsy. J Neurosci, 2012; 32: 14389-401.

[247] Li Y, Peng Z, Xiao B, Houser CR. Activation of ERK by spontaneous seizures in neural progenitors of the dentate gyrus in a mouse model of epilepsy. Exp Neurol, 2010; 224: 133-45. 
[248] Rakhade SN, Yao B, Ahmed S, Asano E, Beaumont TL, Shah AK, Draghici S, Krauss R, Chugani HT, Sood S, Loeb JA. A common pattern of persistent gene activation in human neocortical epileptic foci. Ann Neurol, 2005; 58: 736-47.

[249] Zhu X, Han X, Blendy JA, Porter BE. Decreased CREB levels suppress epilepsy. Neurobiol Dis, 2012; 45: 253-63.

[250] Huang Y, Myers SJ, Dingledine R. Transcriptional repression by REST: recruitment of Sin3A and histone deacetylase to neuronal genes. Nat Neurosci, 1999; 2: 867-72.

[251] Park HG, Yu HS, Park S, Ahn YM, Kim YS, Kim SH. Repeated treatment with electroconvulsive seizures induces HDAC2 expression and down-regulation of NMDA receptor-related genes through histone deacetylation in the rat frontal cortex. Int J Neuropsychopharmacol, 2014; 17: 1487-500.

[252] Haggarty SJ, Tsai LH. Probing the role of HDACs and mechanisms of chromatin-mediated neuroplasticity. Neurobiol Learn Mem, 2011; 96: 41-52.

[253] Binder DK, Croll SD, Gall CM, Scharfman HE. BDNF and epilepsy: too much of a good thing? Trends Neurosci, 2001; 24: 47-53.

[254] Gorter JA, van Vliet EA, Aronica E, Breit T, Rauwerda H, Lopes da Silva FH, Wadman WJ. Potential new antiepileptogenic targets indicated by microarray analysis in a rat model for temporal lobe epilepsy. J Neurosci, 2006; 26: $11083-110$

[255] Rajan I, Savelieva KV, Ye GL, Wang CY, Malbari MM, Friddle C, Lanthorn TH, Zhang W. Loss of the putative catalytic domain of HDAC4 leads to reduced thermal nociception and seizures while allowing normal bone development. PLoS One, 2009; 4: e6612.

[256] Chen B, Cepko CL. HDAC4 regulates neuronal survival in normal and diseased retinas. Science, 2009; 323: 256-9.

[257] Majdzadeh N, Wang L, Morrison BE, Bassel-Duby R, Olson EN, D'Mello SR. HDAC4 inhibits cell-cycle progression and protects neurons from cell death. Dev Neurobiol, 2008; 68: 1076-92.

[258] Hu QP, Mao DA. Histone deacetylase inhibitor SAHA attenuates post-seizure hippocampal microglia TLR4/MYD88 signaling and inhibits TLR4 gene expression via histone acetylation. BMC Neurosci, 2016; 17: 22.

[259] Chen Y, Xie Y, Wang H, Chen Y. [SIRT1 expression and activity are up-regulated in the brain tissue of epileptic patients and rat models]. Nan Fang Yi Ke Da Xue Xue Bao, 2013; 33: 528-32.

[260] Shih J, Liu L, Mason A, Higashimori H, Donmez G. Loss of SIRT4 decreases GLT-1-dependent glutamate uptake and increases sensitivity to kainic acid. J Neurochem, 2014; 131: 573-81.

[261] Li F, Liu L. SIRT5 Deficiency Enhances Susceptibility to Kainate-Induced Seizures and Exacerbates Hippocampal Neurodegeneration not through Mitochondrial Antioxidant Enzyme SOD2. Front Cell Neurosci, 2016; 10: 171.

[262] Frisch C, Husch K, Angenstein F, Kudin A, Kunz W, Elger CE, Helmstaedter C. Dose-dependent memory effects and cerebral volume changes after in utero exposure to valproate in the rat. Epilepsia, 2009; 50: $1432-41$.

[263] Brill J, Lee M, Zhao S, Fernald RD, Huguenard JR. Chronic valproic acid treatment triggers increased neuropeptide y expression and signaling in rat nucleus reticularis thalami. J Neurosci, 2006; 26: 6813-22.

[264] Vezzani A, Sperk G. Overexpression of NPY and Y2 receptors in epileptic brain tissue: an endogenous neuroprotective mechanism in temporal lobe epilepsy? Neuropeptides, 2004; 38: 245-52.

[265] Scharfman HE, McCloskey DP. Postnatal neurogenesis as a therapeutic target in temporal lobe epilepsy. Epilepsy Res, 2009; 85: 150-61.

[266] Jessberger S, Nakashima K, Clemenson GD, Jr., Mejia E, Mathews E, Ure K, Ogawa S, Sinton CM, Gage FH, Hsieh J. Epigenetic modulation of seizure-induced neurogenesis and cognitive decline. J Neurosci, 2007; 27 : $5967-75$.

[267] Hsieh J, Nakashima K, Kuwabara T, Mejia E, Gage FH. Histone deacetylase inhibition-mediated neuronal differentiation of multipotent adult neural progenitor cells. Proc Natl Acad Sci U S A, 2004; 101: 16659-64.

[268] Rossetti F, de Araujo Furtado M, Pak T, Bailey K, Shields M, Chanda S, Addis M, Robertson BD, Moffett M, Lumley LA, Yourick DL. Combined diazepam and HDAC inhibitor treatment protects against seizures and neuronal damage caused by soman exposure. Neurotoxicology, 2012; 33: 500-11.

[269] Brandt C, Gastens AM, Sun M, Hausknecht M, Loscher W. Treatment with valproate after status epilepticus: effect on neuronal damage, epileptogenesis, and behavioral alterations in rats. Neuropharmacology, 2006; 51: 789-804.

[270] Szot P, White SS, Shen DD, Anderson GD. Valproic acid, but not lamotrigine, suppresses seizure-induced cfos and c-Jun mRNA expression. Brain Res Mol Brain Res, 2005; 135: 285-9.

[271] Dong E, Chen Y, Gavin DP, Grayson DR, Guidotti A. Valproate induces DNA demethylation in nuclear extracts from adult mouse brain. Epigenetics, 2010; 5: 730-5.

[272] Milutinovic S, D'Alessio AC, Detich N, Szyf M. Valproate induces widespread epigenetic reprogramming which involves demethylation of specific genes. Carcinogenesis, 2007; 28: 560-71.

[273] Tanis KQ, Duman RS, Newton SS. CREB binding and activity in brain: regional specificity and induction by electroconvulsive seizure. Biol Psychiatry, 2008; 63: 710-20. 
[274] Garriga-Canut M, Schoenike B, Qazi R, Bergendahl K, Daley TJ, Pfender RM, Morrison JF, Ockuly J, Stafstrom C, Sutula T, Roopra A. 2-Deoxy-D-glucose reduces epilepsy progression by NRSF-CtBP-dependent metabolic regulation of chromatin structure. Nat Neurosci, 2006; 9: 1382-7. 